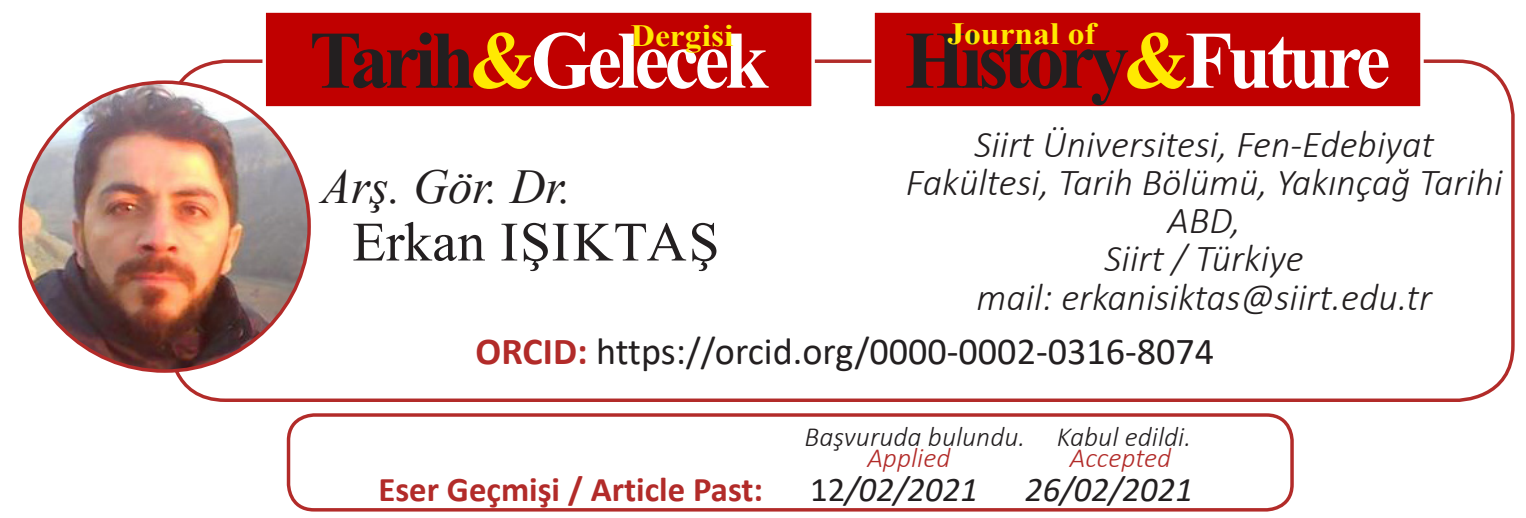

Araştırma Makalesi

DOI: http://dx.doi.org/10.21551/jhf.879308

Research Paper

Orjinal Makale / Orginal Paper

\title{
Osmanl1-Avusturya Devletleri Arasında Uygulanan Gümrük Muamelatı (1838-1851): Tarife, Emtia ve Sorunlar
}

Öz

\author{
Customs Relations Between Ottoman-Austrian States (1838-1851): \\ Tariffs, Commodities and Problems
}

Tarihte siyasi ve askeri rekabetleriyle ön plana çıkan Osmanl1-Avusturya devletlerinin ticari faaliyetleri de bir o kadar dikkat çekici olmuştur. Bu ilişkiler, dönemin siyasi ve iktisadi şartlarına bağlı olarak gelişim göstermiştir. 16. yüzyılda imtiyazlarla başlayan ticari faaliyetlerin hukuksal zemini akd olunan ahitnameler ve antlaşmalarla daha da güçlendirilmiştir. Bilhassa ticaret siyasetinin en önemli vasıtaları olan gümrük ilişkilerinin geliştirilmesi, iki devlet arasındaki ticaret hacminin artmasına neden olmuştur. Söz konusu devletlerin benimsemiş olduğu gümrük ve ticaret siyaseti, ikili ticaretin seyrini etkilemiştir. Osmanl1Avusturya devletleri arasında uygulanan gümrük ilişkilerinde aksaklık yaşandığında ticari ilişkilerin sekteye uğradığı görülmektedir. Bu bağlamda araştırmada; Osmanlı-Avusturya ticari ilişkilerinde uygulanan gümrük muamelatı üzerine odaklanılmıştır. Bu kapsamda incelenen dönem içerisinde uygulamaya konulan tarifeler, ticarete konu olan mallar ve gümrük ilişkilerinde ortaya çıkan sorunların tespiti ele alınmıştır. Tarife hususunda özellikle 1851 tarihli tarife muahedesi irdelenmiştir. Bu tarife üzerinden ithalat ve ihracata konu olan malların orijin bakımından dağılımları ve malların vergilendirme biçimleri incelenmiştir. Son olarak da gümrük sorunlarının neler olduğu, neden kaynaklandığı tespit edilmeye çalışılmıştır.

Anahtar Kelimeler: Osmanlı Devleti, Avusturya, Tarife, Emtia ve Sorunlar.

\section{Abstract}

In history, the commercial activities of the Ottoman-Austrian States, which came to the fore with their political and military rivalries, were just as remarkable. These relations developed depending on the political and economic conditions of the period. In the 16th century, the legal basis of the first commercial activities, which began with capitulations, was further strengthened by agreements and agreements signed. In particular, the development of customs relations, which are the most important means of trade policy, has led to an increase in the volume of trade between the two states. The Customs and trade policy adopted 
by the states in question has influenced the course of bilateral trade. It is seen that trade relations were disrupted when there was a failure in customs relations between the Ottoman-Austrian States. Based on this idea, the research focused on customs treatment applied in Ottoman-Austrian trade relations. In this study, tariffs imposed, goods subject to trade and the detection of problems arising in customs relations were discussed. In particular, the tariff concordat of 1851 was examined. In addition, the forms of taxation of goods were examined. Finally, it was tried to determine what the customs problems were, why they were caused.

Keywords: Ottoman State, Austrian, Tariffs, Commodities and Problems.

\section{Giriş}

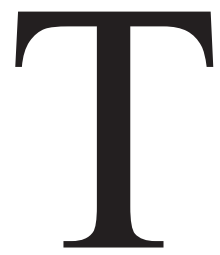

arihsel süreçte Osmanl1-Avusturya ilişkileri, her devirde ehemmiyetini korumuş, yaşanan olaylar dönemlere damgasını vurmuştur. 1526'dan sonra siyasi ve askeri rekabetle başlayan ilişkiler, 20. yüzyılın başlarına kadar devam etmiştir. Her ne kadar çeşitli antlaşmalarla (Zitvatorok, Vasvar, Karlofça, Pasarofça, Belgrad ve Ziştovi) iki devlet arasında bir müddet de olsa sükûnet sağlanmışsa da siyasi şartlara bağlı olarak iki devletin tekrardan karşı karşıya geldikleri aşikârdır. Üç yüz yılı aşkın bir zaman dilimine yayılan bu mücadelenin her iki devlet için de ciddi kayıplara neden olduğunu söylemek mümkündür ${ }^{1}$. Öte yandan siyasi ve askeri mücadelelere rağmen her iki devlet arasındaki ticari ilişkiler de devam etmiştir.

Araştırmada ele alınan dönem öncesinde Osmanlı-Avusturya ticari ilişkilerinin hukuksal zemini, kapitülasyonlar ve ahidnâmelerle verilen ticari imtiyazlara bağlı olarak şekillenmiştir². Bu bağlamda 1606 senesinde akdedilen Zitvatorok muahedesiyle iki taraf arasında ticaret meselesi ele alınmış, ticaretin güvenli bir şekilde yapılmasına karar verilmiştir ${ }^{3} .1615$ senesinde imzalanan ve yirmi yıl geçerli olan on iki maddelik ahidnamede Avusturyalı tüccarların Osmanlı pazarlarındaki faaliyetleri ele alınmıştır. Ahidnamede, iki devlet arasındaki ticaret serbestliğine ve konsolosluk açma konusuna değinilmiştir.

1 Osmanlı-Avusturya ilişkileri hakkında detaylı bilgi için bkz: Hüner Tuncer, Osmanlı-Avusturya İlişkileri (1789-1853), Kaynak Yayınları İstanbul 2008, İ. Hakkı Uzunçarşıll, Osmanlı Tarihi. C.II, Türk Tarih Kurumu Yayınları, Ankara 2016, M. Feridun Emecen, "Çağdaş Osmanlı Kaynaklarında Uzun Savaşlar ve Zitvatorok Antlaşması İle İlgili Algılama ve Yorumlama Problemleri", Osmanlı Araştırmaları Dergisi, C. XXIX, İstanbul, 2007, s. 87-97; Geza Davıd, , "XVI. Yüzyılda Osmanl1-Habsburg Mücadelesinin Bir Kaynağı Olarak Mühimme Defterleri”, Tarih Dergisi, sy. 53, İstanbul 2012, s.295-349; Pal Odor, “Macaristan’a Yönelik Osmanlı Siyaseti, 1520-1541”, C.40, sy.40, Tarih Dergisi, 2004, s. 11-86; Özgür Kolçak, "XVII. Yüzyıl Osmanlı-Habsburg Diplomasi Tarihine Bir Katkı: 1664 Vasvar Antlaşması'nın Tasdik Sürecine Dair Yeni Bulgular”, Dîvân Disiplinlerarası Çalışmalar Dergisi, C. XXII/43, 2017, s. 25-88; Selim Hilmi Özkan, "Karlofça Antlaşması Sonrası Osmanlı Avusturya İlişsilerinde Macarların Durumu”, Avrasya Etütleri, sy.41, 2012, s.183-195; Uğur Kurtaran, "XVIII. Yüzyıl Osmanlı Avusturya Siyasi İlişkileri", Tarih Okulu Dergisi (TOD), sy. XVII, 2014, s.393-419.

2 Uğur Kurtaran, "XVIII. Yüzyılda Osmanlı Devleti İle Avusturya Arasındaki Ticaret Antlaşmaları ve Yaşanan Değişimler", Hitit Üniversitesi Sosyal Bilimler Enstitüsü Dergisi, sy.9, C.2, Aralık 2016, s.746.

3 Sándor Papp, “Zitvatorok Antlaşması”, TDV İslâm Ansiklopedisi, C.44, Türkiye Diyanet Vakfı Yayınları, İstanbul 2013, s.472. 
Yine 1617 yılında başka bir ahidnameyle de ticaret hususu yeniden alınmıştır. Daha sonraki süreçte ticari ilişkilerin ele alındığı yıl 1699 senesidir. Ancak bu tarihte imzalanan Karlofça Antlaşması'nda ticaret ve tüccarlara yönelik meseleler kapsamlı bir şekilde ele alınmamış yalnızca Avusturyalı tüccarların Osmanlı pazarlarında güven içinde ticaret yapabilecekleri, ticari meselelerle ilgilenecek yetkililerinin tayin edileceği ve müste'minlere tanınan haklardan istifade edebileceklerine vurgu yapılmıştır ${ }^{4}$.

1718 tarihli Pasarofça Antlaşması, mezkûr iki devlet arasındaki ticari faaliyetlerin en kapsamlı olarak ele alındığı hukuksal metin olmuştur. Bu antlaşmada; mütekabiliyet esasına vurgu yapılmakla birlikte Avusturyalı tüccarların Osmanlı topraklarında serbest ticaret yapma ve uygun gördüğü yerlerde konsolosluklar açabilmelerine dair birçok hususa yer verilmiştir ${ }^{5}$. Öte yandan 1739 tarihli Belgrad Muahedesi'nde ticaret meselesine çok değinilmemiş, diğer Avrupalı müste'min tüccara tanınan hakların Avusturyalı tüccarlara da tanınması gerektiğine vurgu yapılmıştır. Ticari ilişkilere ilişkin en ayrıntılı düzenlemeler 1747 ve 1784 senelerine ait ahidnâmelerde yapılmıştır. Son olarak 1791 tarihli Ziştovi Antlaşması ile ticari faaliyetlerin hukuksal zemini düzenlenmiştir ${ }^{6}$.

19. yüzyıl öncesinde Osmanl1-Avusturya ticari ilişkilerine konu olan emtiaların ekseriyetini ham veya işlenmiş dokuma malzemesi, gıda maddeleri, hırdavat ürünleri ve çeşitli araç-gereçler oluşturmaktadır. Bu minvalde Avusturyalı tüccarların Osmanlı ülkesinden satın alıp kendi ülkelerine götürdükleri malların arasında; kürk, sahtiyan, sığır, koyun, envai deriler, pamuk, ip, tütün, şarap, şeker, kuru üzüm, baharat çeşitleri, ahşap ve süs eşyası yer almıştır ${ }^{7}$ Diğer yandan Avusturyalı tüccarların Osmanlı Devleti'ne getirdikleri ürünlerin başında mensucat, baharat, ecza, hırdavat ve cam ürünleri bulunmaktadır ${ }^{8}$. Bu ürünler, kara, deniz ve nehir yolu üzerinden nakledilmiştir. Bu bağlamda Avusturyalı tüccarlar, Tuna nehri üzerinden Karadeniz'e ulaştıkları gibi Trieste ve Venedik üzerinden de mallarını nakletme firsatı elde etmişlerdir ${ }^{9}$.

İncelenen dönem öncesinde ticari ilişkilerin hukuksal yapılanması ve ticarete konu olan emtianın dağılımı bu şekilde iken gümrükler hakkında da bilgi vermekte fayda vardır. Aslında iki devlet arasındaki gümrük muamelatına ilişkin ilk hukuksal düzenlemeler Pasarofça ticaret ahidnamesinde ele alınmışıtır. Bu ahidnamemin 3. maddesinde; her iki tarafın tüccarlarının kara, deniz ve nehir yoluyla Osmanlı Devleti'ne getirdikleri ve Osmanlı topraklarından satın alıp kendi memleketlerine götürdükleri emtiadan \% 3 oranında gümrük vergisi ile 300 akçe selamet akçesinden başka vergi alınmayacağ belirtilmiştir $^{10}$. Öte yandan bu ahidnamede gümrük ile

4 Numan Elibol, XVIII. Yüzyılda Osmanl-Avusturya Ticareti, (Yayınlanmamış Yüksek Lisans Tezi), Marmara Üniversitesi, Türkiyat Araştırmaları Enstitüsü Yeniçağ Tarihi Bilim Dalı, İstanbul 2003, s.2628.

$5 \quad$ Kemal Beydilli, "Avusturya”, Türkiye Diyanet Vakfı İslâm Ansiklopedisi. C.4, Türkiye Diyanet Vakfı Yayınlar1, İstanbul 1991, s.175.

6 Ziştovi Antlaşması ile ilgili bkz: Zülfiye Koçak," "Son Osmanl1-Avusturya Mücadelesinde Değiş̧en Dengeler Ziştovi Antlaşması", Akademik Bakış, sy 22, C.11, 2018, s.261-289.

7 Elibol, a.g.t, s. 28.

8 Mesud Küçükkalay- Numan Elibol, "Osmanlı İmparatorluğu'na Avrupa'dan Karayolu ile Yapılan İhracatın Değerlendirilmesi: 1795-1804”. Osmangazi Üniversitesi Sosyal Bilimler Dergisi, 2003, sy.2, s.170.

9 Ahmet Zeki İzgüer, “Osmanlı İmparatorluğu Tarafından Avusturya'ya Verilen Ticari İmtiyazlara Dair”, Türk Dünyası Araştırmaları Dergisi, sy.58, s.79.

10 Nilgün Bozkurt, “XVIII. Yüzyılın Başlarında Osmanlı-Avusturya Ticari Münasebetleri”, Tarih 
ilgili karar, 18. yüzyılın sonlarında uygulamaya konan düzenlemelerde geçerliliğini korumuştur. Haddizatında gümrükte husule gelen problemlerin başında; çifte vergilendirme ve tarifeden fazla vergi talepleri gelmiştir ${ }^{11}$. Bu sorunlar, Avusturyalı tüccarlar tarafından hem 18. yüzyılda hem de ele alınan dönem içerisinde sıklıkla dile getirilmiştir.

19. yüzyıla gelindiğinde söz konusu devletlerin ticari ilişkilerine yön veren gümrük muamelatında önemli değişiklikler yaşanmıştır. Bu itibarladır ki çalışmada, Osmanlı-Avusturya gümrük ilişkileri kapsamında uygulamaya konulan tarifeler, ticarete konu olan mallar ve gümrükte yaşanan sorunlar irdelenmiştir. Araştırmanın zamansal dilimini 1838-1851 yılları oluşturmaktadır. Bu dönemin seçilmesinde siyasi ve iktisadi gelişmelerin mühim bir rol oynadığını söylemekte fayda vardır. Zira 1838 yılında Osmanl1-İngiltere arasında uygulamaya konulan yeni ticaret antlaşması neticesinde Osmanlı gümrük merkezlerinde uygulanan tarife önemli değişikliklere maruz kalmış ve uluslararası ticaret de buna binaen şekil almaya başlamıştır. 1851 yılına gelindiğinde ise on üç yıldır yenilenemeyen tarife antlaşmasının son bulduğu dönemdir. Bu nedenledir ki ele alınan zaman aralığında söz konusu iki devlet arasındaki gümrük ilişkileri üzerine odaklanılmıştır. Çalışmanın temel problematikleri üç ana husus üzerinden oluşturulmuştur. Bunlardan ilki tarife meselesidir. Hakikaten ticari ilişkilerin sağlıklı yürütülebilmesi ancak güçlü bir gümrük zemininin oluşturulmasına bağlıdır. Bu düşünceyledir ki incelenen dönem içerisinde mezkûr iki devlet arasında kabul gören tarifeye mahsus muahedeleri tespit etmek, hükümlerini incelemek, mukayese etmek ve ticari ilişkilere olan katkılarını irdelemek için tarife konusu ele alınmıştır.

Araştırmada incelenen diğer bir husus ise gümrüklendirmeye tabi olan emtialardır. Bir başka ifade ile ticarete konu olan mallardan alınacak olan gümrük vergisinin nasıl tayin edildiğidir. $\mathrm{Bu}$ kapsamda ticarete konu olan malların orijini, vezin biçimi, kıymetleri ve kıymetleri üzerinden hangi orandan vergi alınacağı irdelenmiştir. Araştırmanın diğer bir amacıysa toplam ürün içerisinde rayice bırakılan ürünleri açığa çıkarmaktır. Bu bağlamda çalışmada; özellikle 1851 tarihli tarife üzerinden ticarete dâhil edilen emtiaların dağılımı, ölçü birimleri, kıymetleri ve vergi dilimleri açığa çıkartılmaya çalışılmıştır. Son olarak da incelenen dönem içerisinde gümrük ilişkilerinde ortaya çıkan sorunlar üzerinde durulmuştur. Bu doğrultuda sorunların neler olduğu, neden kaynaklandığı tespit edilmeye çalışılmıştır. Ayrıca sorunların çözümü noktasında mezkûr devletlerin tutumları irdelenmiştir.

\section{Gümrük İşlemlerinde Uygulanan Tarifeler}

Osmanl1-Avusturya ticari ilişkilerine yön veren gümrük muamelatını anlamak ve aktarabilmek için Osmanlı gümrük rejiminin iyi bilinmesi gerekmektedir. Bu düşünceyledir ki Osmanlı gümrük rejimi hakkında genel mahiyette bilgi verilmesi elzem olmuştur. Bu bağlamda Osmanlı gümrük sistemi, iki açıdan değerlendirilebilir. Bunlardan biri iç, diğeri dış gümrüklerdir. İç gümrük rejimi, ticari faaliyetlerin yoğunlaştığı şehir ve güzergâhlar etrafında şekillenmiştir. Bunun yanında küçük ölçekte ticari kapasiteye sahip olan şehirlerde de bu uygulamanın izlerini görmek mümkündür. Bu noktalar üzerinde vücuda getirilen gümrük kapılarında, gümrüğe gelen ticari eşyanın giriş ve çıkış işlemleri kayıt altına alınmıştır. Eğer gümrüğe gelen mallar o şehirde satılacaksa belirlenen usul ve kaideler çerçevesinde -ki genelde kıymet esasına göre- malların vergisi tahsil edilmiştir ${ }^{12}$.

Incelemeleri Dergisi, sy.1, C.12, 1997, s.186.

11 Elibol, a.g.t., s. 37-38, Bozkurt, a.g.m., s.191.

12 Mehmet Genç, Osmanli'da Devlet ve Ekonomi, Ötüken Neşriyat, İstanbul 2014, s. 210. 
Malın gümrüğe girişiyle birlikte tahsil edilen vergi çeşidi amediye olmuştur. Ancak mal gümrükten çıkarılacaksa o zaman da reftiye vergisi alınmıştır. Fakat mal başka bir yere transfer edilecekse müruriye vergisine tabi tutulmuştur ${ }^{13}$. Öte yandan iç gümrük rejimi içerisinde değerlendirilen ama daha çok geçit ve konaklama noktalarının güvenliğini sağlamak maksadıyla vücuda getirilen bac merkezlerinde de "bac" adı verilen, malın 1/10 ile 1/50 oranında değişen miktarlar üzerinden vergi tayin edilmiştir. Diğer yandan iç gümrüklerde alınan liman, kantar, delaliye ve ihtisab gibi sair vergiler de bulunmaktadir ${ }^{14}$.

Osmanlı dâhili/iç gümrükleri; kara, sahil ve sınır gümrükleri adı altında üç sınıfa ayrılmıştır. Kara gümrüklerinde genelde iç ticarete konu olan malların gümrük muamelatları yapılırken sahil gümrüklerinde iç ve dış ticarete konu olan malların işlemleri yapılmıştır. Kara yoluyla yapılan ticaret ağının gelişmesine bağlı olarak yeni gümrüklerin kurulması ihtiyacı hâsıl olmuştur. Bu bağlamda Bursa, Erzurum, Tokat, Diyarbakır, Bağdat, Şam, Halep, Edirne, Belgrad gibi önemli ticaret merkezlerine yakın yerlerde küçük kara gümrükleri ihdas edilmiştir. Ancak bu merkezler, 1843 senesine kadar uygulamada kalmıştır. Kadim olan kara gümrükleri ise 1874 yılında lağvedilmiştir. Sahil gümrük merkezleri ise 20. yüzyılın başlarına kadar varlıklarını devam ettirmiştir ${ }^{15}$.

İç gümrük vergisi tayin edilirken bazı kaideler dikkate alınmıştır. Bunlardan ilki dindi. Yani Müslim ile gayrimüslim ayrımı bariz bir şekilde -diğer hususlarda olduğu gibi- vergi miktarının belirlenmesinde etkisini hissettirmiştir ${ }^{16}$. Hatta gayrimüslim ahalinin de Osmanlı tebaasından olup olmadı̆̆ına bakılmıştır. Bunun dışında kendisinden önceki Türk-İslam devletlerinin vergi uygulaması hususundaki usul ve kaideler ile birlikte fethedilen bölgelerin kanun ve nizamlarını pek fazla değiştirilmeden devam ettirilmiştir. Bu nedenledir ki uygulamaya konulan gümrük vergisi de bölgeden bölgeye farklılık göstermiştir ${ }^{17}$. Esas itibarıyla Osmanlı' da uygulanan dâhili gümrük vergisi; Müslim tebaa \% 3, zimmîler \% 4 ve Osmanlı tebaasından olmayan gayrimüslimler \% 5 üzerinden belirlenmiştir. Bu oranlar, 16. yüzyılın sonlarına kadar devam etmiştir. Ancak uygulamada olan vergi dilimleri, siyasi ve iktisadi şartlara bağlı olarak zamanla esneklik göstermiştir. Bu bağlamda 16. yüzyılın sonlarında artan mali sorunlarla birlikte yeniçerilerin temel besin kaynağ1 olan et fiyatlarının da hızlı bir artış göstermesi sebebiyle dâhili gümrüklere "zarar-1 kassâbiyye" adı altında \% 1'lik zam yapılmıştır. Böylece Müslim tebaanın ödediği vergi \% 4'e, zimmîlerinki \% 5'e ve tebaadan olmayan gayrimüslimlerin vergisi ise $\% 6^{\prime}$ ya çıkartılmıştır ${ }^{18}$.

1590’larda yürürlüğe konulan yeni gümrük vergilerinin tam olarak uygulandığı söylenemez. Zira dâhili vergiler, Osmanlı Devleti'nin her yerinde malın kıymeti üzerinden alınmamıştır. Bazı gümrük merkezlerinde vergiler yük başına tahsil edilmiştir. Sonraki dönemde de benzer uygulamalar devam etmiştir. Ancak 18. yüzyılın sonlarıyla birlikte Osmanlı tebaasından olan gayrimüslimler, hammaddeyi daha ucuza temin etmek için konsolosluklarda tercümanlık işleriyle ilgilenmeye başlamış, elde ettikleri berat ile "beratlı tüccar" sıfatında hareket etmeye başlamıştır. Zimmîlere önemli ayrıcalıklar sunan bu imtiyaz neticesinde İthalat ve ihracat vergileri, \% 5'lik

13 S. Mübahat Kütükoğlu, "Osmanlılarda Gümrük”, TDV İslâm Ansiklopedisi, C.14, Türkiye Diyanet Vakfı Yayınları, İstanbul 1996, s.263.

14 Celal Yeniçeri, "Bâc", TDV İslâm Ansiklopedisi, Türkiye Diyanet Vakfı Yayınları, İstanbul 1991, s.412.

15 Genç, a.g.e., s.200.

16 Turhan Atan, Türk Gümrük Tarihi II. Ata Ofset Matbaac1lık, İstanbul 1995, s.95.

17 Kütükoğlu, a.g.m, s.264.

18 Atan, a.g.e., s.95. 
vergi yerine \% 3 üzerinden ödenmiş̧ir. Bu durum da Osmanlı Devleti'nin kayda değer bir miktarda gelir kaybetmesine neden olmuştur ${ }^{19}$.

Öte yandan Osmanlı tebaasından olmayan yabancı tüccarların gümrük bedelleri de \% 6 üzerinden seyretmeye devam etmiştir. Bu vergi diliminin değişmesinde etkili olan en kritik safha 1838 tarihidir $^{20}$. Zira belirtilen tarihte Osmanl1-İngiltere arasında imzalanan Balta Limanı Ticaret Antlaşması'na göre dâhili vergiler yeniden tanzim edilmiştir ${ }^{21}$. Buna antlaşmaya göre; mevcut kapitülasyonlar tarafından tanınan tüm haklar süresiz olarak teyit edilmiş, tüm tekeller kaldırılmış, İngiliz mallarının ülkeye girişinde $\% 3$ vergisi esas alınmış ve Osmanlı pazarlarından satın alınacak mallar da kıymetleri üzerinden \% 9 amediye ve eğer mal ihraç edilecekse \% 3'lük reftiye vergisine tabi tutulmuştur ${ }^{22}$. Tabi Osmanlı gümrük rejiminin değişmesinde etkili olan 1838 tarihli ticaret antlaşması, İngiltere'ye münhasır kalmamıştır. Diğer Avrupalı devletler de bu tür imtiyazlara sahip olmak için Osmanlı Devleti ile diplomatik ilişkiler kurma yoluna gitmiştir. Bu doğrultuda 1839'da İspanya, Sardunya, Felemenk, 1840'ta Belçika ve Prusya, 1841'de Danimarka, Toskana, İsveç, 1843 'te Portekiz, 1846 'da Rusya gibi devletler Osmanlı Devleti'yle imtiyaz antlaşması yapmıştır²3.

Gerçekten de Osmanl1-Avusturya ticari ilişkilerine şekil veren gümrük muamelatının 1838 yılına kadar yukarıda ifade edilen usuller ve iki devlet arasinda akd olunan yasal metinler çerçevesinde yürütüldüğünü söylemek mümkündür. Ne var ki 1838 yılı, Osmanlı iktisadi ve ticari hayatının dönüm noktası olmuştur. Bu süreçte husule gelen gelişmeler, Osmanlı gümrük nizamını ve işleyişini önemli ölçüde değiştirmiştir. Diğer devletlerde olduğu gibi Avusturya da Osmanlı Devleti'yle olan mevcut ticaret antlaşmasını yenilemek için çalışmalara başlamıştır. 19. yüzyılın başlarında Osmanlı-Avusturya ticari ilişkilerine yön veren tarife muahedesi 1818 senesine aittir. Hicri 1233 (1818) senesinin mart ayından itibaren yürürlükte olan ticaret muahedesinin kararları, on dört sene yürürlükte kalmış ve iki devlet arasındaki ticari ilişkiler buna binaen yürütülmüştür ${ }^{24}$. Tarifede, Avusturya tüccarlarının satın alacakları Osmanlı emtia ve eşyasının klymeti cariyesine göre \% 3 üzerinden vergilendirileceği ifade edilmiştir. Ayrıca on dört yıllık sürenin dolması halinde de yeni tarifenin malın o dönemdeki kıymetine göre yeniden tanzim olunması gerektiğine vurgu yapılmıştır25. Böylece 1818-1832 yılları arasında Osmanlı-Avusturya devletleri arasındaki ticari ilişkiler bu tarifeye istinaden şekil almıştır.

Hicri 1250 (1833-1834) y1lına gelindiğinde mevcut tarifenin yenilenmesi hususu tekrardan gündeme gelmiş ve iki devlet arasında diplomatik görüşmeler yapılmıştır. Bu doğrultuda Osmanlı Devleti, ticari ilişkilerde ortaya çıkacak gümrük problemlerinin önüne geçmek maksadıyla Avusturya Sefareti ile bağlantı kurmuştur. Bu hususta Osmanlı Devleti tarafından hazırlanan takrir, Avusturya

19 Ali İhsan Bağış, Osmanlı Ticaretinde Gayrimüslimler, Turhan Kitapevi, Ankara 1983, s.28.

20 Şerif Mardin, “Tanzimat'tan Cumhuriyete İktisadi Düşüncenin Gelişmesi (1838-1918)”, Tanzimat'tan Cumhuriyet'e Türkiye Ansiklopedisi, C.3, İletişim Yayınları, İstanbul 1985, s.621.

21 Balta Limanı ticaret antlaşmasına giden süreçle ilgili detaylı bilgi için bkz: S. Mübahat Kütükoğlu, Balta Limanına Giden Yol Osmanlı-İngiliz İktisadi Münasebetleri (1580- 1850), Türk Tarih Kurumu Yayınlar, Ankara 2013.

22 Seyfettin Gürsel, "1838 Osmanl1-İngiliz Ticaret Antlaşması”, Tanzimat'tan Cumhuriyet'e Türkiye Ansiklopedisi, C.3, İletişim Yayınları, İstanbul 1985, s.689.

23 Necdet Kurdakul, "Ticaret Antlaşmaları", Tanzimat'tan Cumhuriyet'e Türkiye Ansiklopedisi, C.3, İletişim Yayınları, İstanbul 1985, s.666.

24 BOA, C.HR, 133/6621, 30 Nisan 1818/23 Cemaziyelahir 1233.

25 BOA, C.HR, 41/7033, 28 Kasim 1818/29 Muharrem 1234. 
Sefareti aracılı̆̆ıyla Avusturya Devleti'ne iletilmiştir ${ }^{26}$. Ancak siyasi ve iktisadi problemlerden ötürü mevcut tarifenin yenilenmesi 1839'lara kadar sarkmıştır. 1833-1839 yılları arasındaki safhada gümrük muamelatı eski tarife üzerinden yürütülse de yeni tarifenin yenilenememesi iki devlet arasındaki ticari ilişkileri zaman zaman sekteye uğratmıştır. Bilhassa vergi tayini noktasında tüccar ve gümrükçü arasında husule gelen tartışmalar, iki devlet arasındaki tarife problemini daha da arttırmıştır.

1839 yılına gelindiğinde Osmanlı ile Avrupalı devletler arasında yedi yıllık -klymet esasina göre- ticaret muahedesi imzalanmıştır. Böylece Osmanlı Devleti'ne gelen yabancı tüccarlara uygulanacak olan tarifenin usul ve kaideleri belirlenmiştir ${ }^{27}$. Hakeza Osmanl1-Avusturya devletleri arasında yapılan görüşmeler neticesinde; eski tarife yenileninceye kadar İngiltere ve Fransa devletleriyle akdedilmiş olan ticaret tarifesinin nizam ve şartlarına uygun olarak Avusturyalı tüccarların ticari faaliyetlerini yürütmesine karar verilmiştir ${ }^{28}$. Böylece 1833 yılında nihayete eren ve güncellenemeyen Osmanl1-Avusturya arasındaki tarife meselesi, 1839 y1lında uygulamaya konulan bu kararla yedi yılllı̆̆ına halledilmiştir.

Osmanl1-Avusturya devletleri arasındaki mevcut tarifenin yenilenmesine ilişkin çalışmalar, Hicri 1260 (1845) yılında yeniden gündeme gelmiştir. Bu bağlamda Bâb-1 Âlî̀de yapılan görüşmelerde, devlet erkânının fikri yeni tarifenin süratle yürürlüğe girmesi yönünde olmuştur. Hatta yeni tarifenin tanzimi meselesiyle ilgilenen Meclis-i Vâla, 9 Ocak 1845 tarihinde eski tarifeler ile gümrük işlemleriyle ilgili diğer evrakların incelenmesi gerektiği yönünde karar almıştır² ${ }^{29} 1$ Mayıs 1846 tarihinde Osmanl1-Avusturya devletleri arasında tanzim edilecek yeni tarifenin müzakeresine Hariciye Nazırı Mehmed Emin Âlî Paşa, Darphane Nazırı Mehmed Tahir Bey, İstanbul Gümrüğü Emini Mehmed Tevfîk Bey görevlendirilmişti ${ }^{30} .21$ Aralık 1846 tarihinde gümrük eminliğine gönderilen başka bir tezkirede müzakerelerin başlanması istenmiştir ${ }^{31}$. Öte yandan ticaretle ilgili tarifelerin yenilenmesi hususu sadece Avusturya Devletine münhasır değildi. Diğer Avrupalı devletlerin ticari ilişkilerine yön veren eski tarifelerinin de güncellenmesi gerekiyordu. Osmanlı Devleti, bu hususa ehemmiyet göstermekte, gümrük gelirlerinde husule gelecek gelir kaybının önüne geçebilmek için gerekli çalışmaları yapmaktaydı. Bu bağlamda Osmanlı Devleti'nin uygulamaya koyduğu ilk tedbir, yeni tarifeler yenilene kadar Avrupalı tüccarların Memalik-i Mahrûsa memleketine nakl ve ihraç ettikleri emtia ve eşyanın gümrük işlemleri, eski tarifelere göre yapılması olmuştur. Böylece eski tarifelerin, hicri 1263 senesi muharrem ayının on üçüne (1 Ocak 1847) kadar geçerli olduğu gümrük emanetiyle sefaretler arasında kararlaştırılmış ve taşra gümrüklerine bildirilmesi uygun görülmüştür ${ }^{32}$.

Osmanlı Devleti, harici gümrüklerdeki ticari işlemleri, eski tarifeler üzerinden yürütse de yeni tarifelerin tesisi hususuna da azami ölçüde hassasiyet göstermiştir. Bu doğrultuda 5 Cemaziyelahir 1264 (9 Mayıs 1848) senesinde Avusturya ile olan eski tarifenin yenilenmesine ilişkin müzakerelere girişilmişse de, müzakereler olumlu neticelenememiştir. Zira bu süreçte husule gelen

26 BOA, HAT, 961/41195, 28 Nisan 1835/29 Zilhicce 1250.

27 BOA, A.DVN.NMH, 39/18, 25 Ekim 1851/29 Zilhicce 1267.

28 BOA, A.DVNS.DVE.d, 67/11 Numaralı Nemçe Ahkam Defteri, M.1839-1868/ H.1255-1285.

29 BOA, A.MKT,19/78, 9 Ocak 1845/29 Zilhicce 1260.

30 BOA, MFB, 1325, 24 Kasim 1846/5 Zilhicce 1262.

31 BOA, A.MKT, 59/28, 1 Mayıs 1846/5 Cemaziyelevvel 1262.

32 BOA, A.MKT, 126/53, 9 Mayıs 1848/ 5 Cemaziyelahir 1264. 
1848 ihtilallerinden ötürü Avusturya Devleti, yeni tarifenin hazırlanması için gerekli müzakerelerin yapılamayacağını Osmanlı'ya bildirmiştir. Hatta mezkûr ihtilalin İngiltere ve Fransa devletlerine de sirayet ettiği ve bu devletlerle de nihayet eren tarifelerin de güncellenmesinin zor olacağına dikkat çekilmiştir ${ }^{33}$. Yine başka bir belgede Avrupa'nın içinde bulunduğu siyasi ahvalden ötürü tarifelerin yenilenemediğine işaret edilmiştir. Bunun üzerine Osmanlı Devleti, Avrupalı tüccarların malları eski tarife ahkâmına göre vergilendirilmesini kararlaştırmıştır ${ }^{34}$.

Osmanl1-Avusturya ticari ilişkileri, her ne kadar eski tarifeler üzerinden yürütülmeye çalış1lsa da tarifelerin yenilenmesi hususu sürekli mevzu bahis olmuştur. 1851 yılına gelindiğine Osmanlı Devleti ile Avusturya Sefareti beyninde mezkûr mesele yeniden görüşülmüş ve ticari ilişkilerde uygulanacak yeni bir tarife tanzim olunmuştur. Buna göre Avusturya tebaası tüccarlarının Osmanlı Devleti'ne götürdükleri ve oradan satın alacakları emtiadan ihracat $\% 16$, ithalat vergisinin $\%$ 20 oranında indirilmesine karar verilmiştir. Bu kapsamda olan ihracat mallarına \% 16 indirim yapıldıktan sonra \% 9 amediye ile \% 3 reftiye esasına göre vergilendirilmiştir. Diğer taraftan ithal malları da kıymetinden $\% 20$ tenzilinden sonra \% 3 amediye göre vergi alınması kararlaştırılmıştır ${ }^{35}$. Ayrıca söz konusu tarife muahedesinde yer almayan ya da ismi olup da kıymeti belirlenmeyip rayice bırakılan emtia, rayiç ve kıymetine göre hesaplandıktan sonra vergilendirilmesi uygun görülmüştür. Böylece Osmanl-Avusturya ilişkilerini tayin edecek olan bu tarifenin geçerliliği 1862 yılına kadar sürmüştür. 1862 yılına gelindiğinde yalnızca Avusturya ile değil diğer Avrupalı devletlerle olan ticari ilişkileri tanzim eden tariflerin yenilenmesi meselesi tekrardan gündeme gelmiştir.

Görüldüğü üzere incelenen dönem içerisinde söz konusu iki devlet arasında tarifelerin yenilenememesi meselesi sürekli mevzu bahis olmuştur. Osmanlı Devleti’nin bu husus karşısındaki tavrı dikkate şayandır. Çünkü tarifelerin güncellenmemesi durumunda gümrük gelirlerinde meydana gelebilecek zararın bilincinde olan Osmanlı Devleti'nin meseleye olabildiğince ihtiyatlı davrandığını söylemek mümkündür. Ayrıca Avusturyalı tüccarların gümrük merkezlerinde tarife meselesinden ötürü karşılaşacakları sorunları gidermek için de süresi geçmiş eski tarifeleri uzatması bunu kanitlar niteliktedir.

Öte yandan dönemin siyasi şartları da tarifelerin güncellenmesini geciktiren belli başlı dinamikler arasında yer almıştır. 1848 yılında Avrupa'da baş gösteren 1848 ihtilalleri her ne kadar siyasi bir ihtilal olarak sirayet etse de diş politikada tarifelerin yeniden güncellenmesine mani olduğu dikkat çekici bir sonuç olarak tespit edilmiştir. Bundan dolayı diğer devletlerle de olduğu gibi Avusturya ile olan eski tarifenin yenilenmesi; ancak 1851 yılında gerçekleşebilmiştir. Bu noktada bilhassa 1851 tarihli tarife nizamına dikkat çekmekte fayda vardır. Zira Osmanl1Avusturya devletlerinin 1839-1851 yılları arasındaki ticari ilişkilerini tertip eden özel bir tarife bulunmamaktaydı. Yalnızca 1839 yılında Osmanlı Devleti ile diğer devletler arasında yedi yıllık -rayiç esasına göre- ticaret muahedesi yapılmış olup, Avusturyalı tüccarlar da buna dâhil edilmiştir. Ancak 1851 tarihli tarifeyle Avusturyalı tüccarların Osmanlı Devleti'ne getirecekleri ve götürecekleri malların gümrük bedelleri tayin edilmiştir. Bu nedenledir ki 1851 tarihli tarifenin iki devlet arasındaki ticarette oldukça kıymetli bir yeri olduğu düşünülmektedir. 


\section{Ticarete Konu Olan Emtialar}

Tarihsel süreçte siyasi olduğu kadar ticari bağlamda da sıkı münasebetler içerisine giren Osmanlı-Avusturya devletlerinin ticari ilişkilerine konu olan emtianın eksiksiz bir şekilde tespit edilmesinin oldukça zor olduğunu ifade etmek gerekmektedir. Ancak ticari ilişkilere yön veren tarifeler ışığında dış ve iç ticarete konu olan belli başlı malların açığa çıkarılması mümkün olabilmektedir. Bu itibarladır ki incelenen dönem içerisinde yürürlüğe giren 1851 tarihli tarife defterinden hareketle mezkûr devletlerin ticari ilişkilerine konu olan emtianın ürün bazındaki dağılımını ortaya koymak mümkün olabilmektedir. İlgili tarifede toplamda dört yüz elli üç (453) adet emtianın kaydı bulunmaktadır (Bkz: Grafik 1).

Grafik 1. 1851 Tarihli Tarife Defterine Göre Osmanlı-Avusturya Ürünlerinin Miktarı

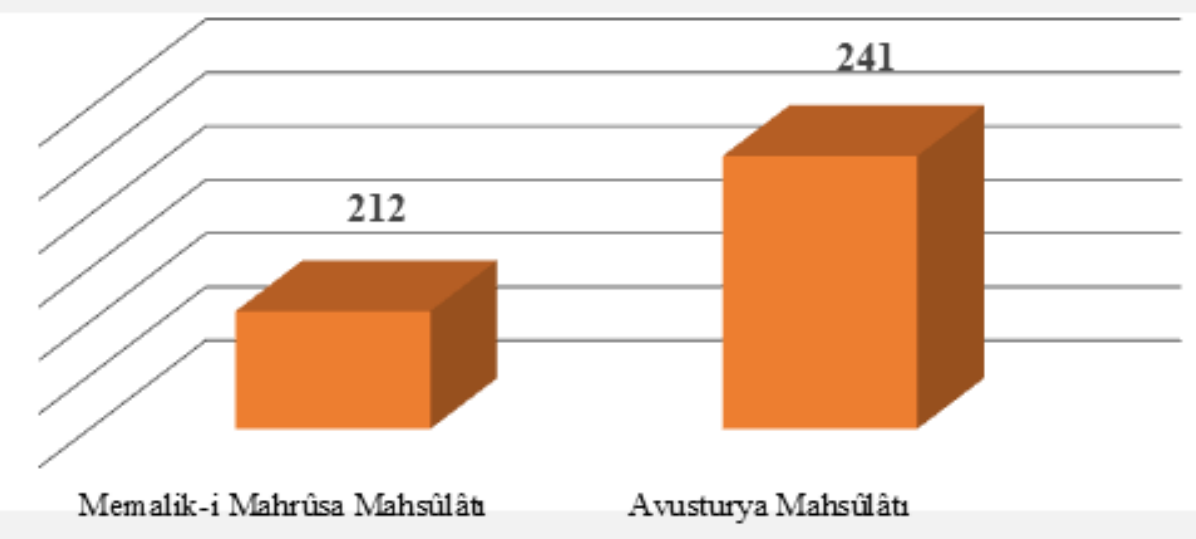

Kaynak: BOA, A.DVN.NMH, 39/18, s.1-34; 67/11 Numaralı Nemçe Ahkam Defteri, M.1839-1868/ H.1255-1285.s.144-173.

İrdelenen tarife defterine göre ikili ticarete konu olan ve kayda geçirilen total malların 241'ini Avusturya, 212'sini Osmanlı mahsulatı teşkil etmektedir. Bu minvalde bakıldığında OsmanlıAvusturya devletlerinin ticari ilişkileri iki sınıfta değerlendirilebilir. Bunlardan ilkini, Avusturyalı tüccarların Osmanlı Devleti pazarlarına getirdikleri hem Avusturya hem de diğer Avrupalı devletlerin ürettiği mallar oluşturmaktadır. Diğeri; Memalik-i Mahrûsa mahsulü sanayi, arazi ve zanaat ürünleridir. Yapılan incelemeler neticesinde Avusturya'dan Osmanlı Devleti'ne ihraç edilen emtiaların ekseriyetle dokuma ve giyim malzemesi, gıda maddeleri, mutfak araç-gereçleri, ağaç ürünleri, hırdavat ve muhtelif eşyalardan oluştuğu anlaşılmıştır (Bkz: Grafik 2). 
Grafik 2. 1851 Tarihli Tarife Defterine Göre Avusturya'dan Osmanlı Devleti'ne İhraç Edilen Emtianın Dağılımı (Adet)

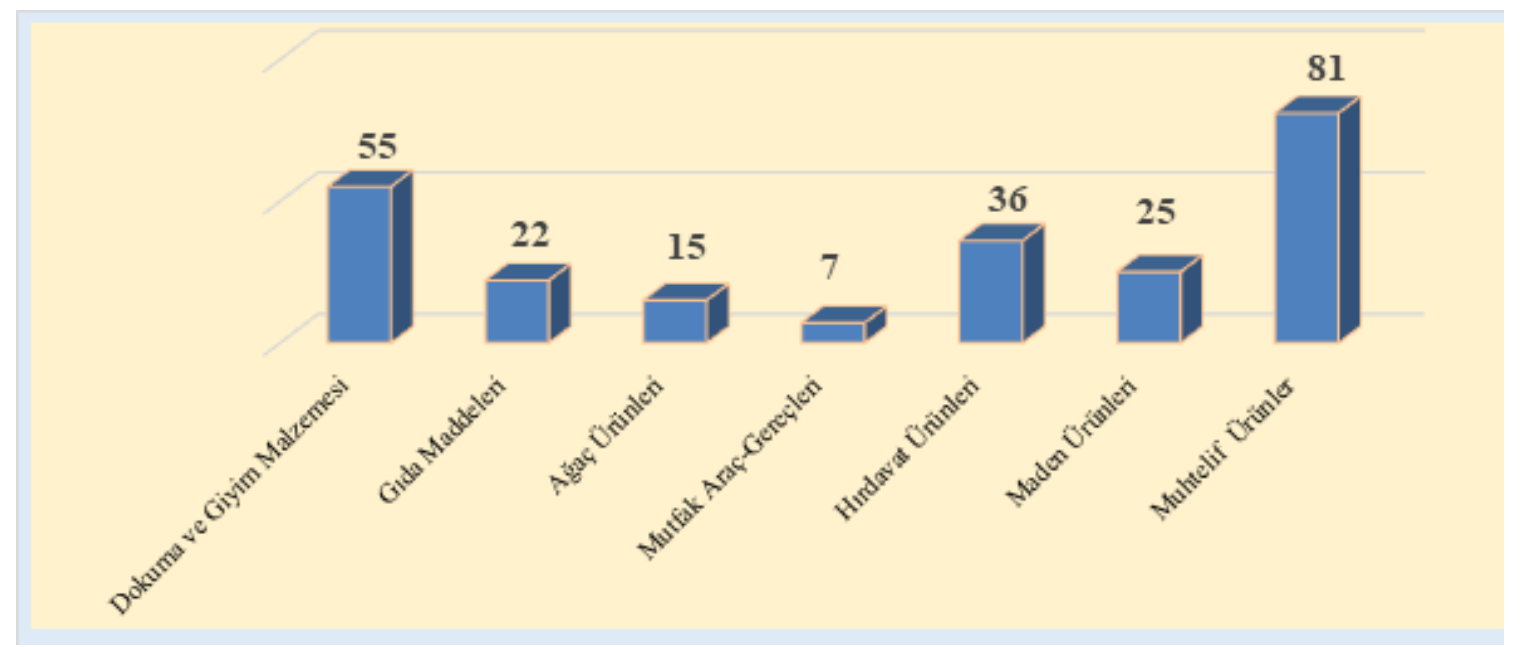

Kaynak: BOA, A.DVN.NMH, 39/18, s.1-34; 67/11 Numaralı Nemçe Ahkam Defteri, M.1839-1868/ H.1255-1285.s.144-173.

Avusturyalı tüccarların Osmanlı pazarlarına getirdikleri mallar genel olarak tasnif edildiğinde "dokuma ve giyim malzemesi” başlığı altında yer alan ürünlerin sayıca en kalabalık grubu teşkil ettiği görülmektedir. Esasen bu gruptaki dokuma mallarının büyük bir kesimi; çûhâ, elvan, basma, kalice, keten, sahtiyan ve bürümcekten meydana gelmektedir. Ayrıca yün çoraplar, hasır şapkalar, elvan eldivenler, feracelik ve pantolonluk kumaşlar da ticarete dâhil olan diğer dokuma ürünleri arasında yer almıştır.

Dokuma ürünlerinin yanı sıra dikkat çeken diğer bir emtia grubu ise hırdavat ürünleridir. Bunlarda; envaî boyalar, sepetler, sandıklar, boncuklar, tenekeler, saat ve pencere camları, Venedik ve Triestekâri şişeler, zift ve neft yağları, balık oltası ve iğnesi, çeşitli aynalar, çini, kundura firçası ve çok amaçlı çekmecelerden oluşmaktadır. Yine maden ürünleri kapsamında; demir, civa, çivi, kömür, kükürt, kurşun, sac ve tel eşyasının ön planda olduğu anlaşılmıştır. Gıda ticareti bağlamında da sucuk, pastırma, balık ve balık yağı, tuzlu et, süt, kuru bakliyat, çikolata, zencefil, karanfil, biber, limon suyu, limon ve portakal kabuğu gibi belli başlı ürünler bulunmaktadır. Ağaç ürünleri adı altında ticarete konu olan ürünler ise ekseriyetle kâğıttan müteşekkildir.

Öte yandan topraktan yapılmış fincan çeşitleri, kemik ve boynuz sapından yapılmış çatal ve bıçak takımları, kalay ve demirden mamul edilmiş kaşıklar ve çatallar, çay ve sofra takımları adı altında gelen ürünler de mutfak araç-gereçleri grubunda sınıflandırılmıştır. Bu emtia grubu, diğerlerine kıyasla ticari ilişkilere daha az konu olmuştur. Bununla birlikte ilgili grafikte sayı bakımından dikkat çeken ve "muhtelif ürünler" başlı̆̆ı altında verilen emtianın farklı kalemlerden oluştuğu için bu başlık altında toplandığını ifade etmek gerekmektedir. Mesela Macaristan şapı, fildişi, kına, roğan pelesenk, çıngırak ve inci gibi çeşitlilik arz eden ürünler de bu grupta yer almıştır. Ayrıca Avusturya dilinde telaffuz edilen bazı emtialar ile tarife listesinde bulunan ancak okunamayan mallar da bu gruba dâhil edilmiştir. Netice itibarıyla Avusturya mahsulü ürünler genel olarak değerlendirildiğinde öncelikle çeşitlilik arz ettiğini söylemek mümkündür. Bilhassa işlenmiş ürünlerin Osmanlı pazarlarına transfer edildiği anlaşılmaktadır. Hakeza Avusturyalı tüccarların Osmanlı Devleti'nden satın aldıkları ürünlere bakıldığında ham ve işlenmiş dokuma ürünleri, gıda 
ve boya eşyası, envai deri emtiası ile birtakım muhtelif ürünleri tercih ettikleri sonucuna varılmıştır (Bkz: Grafik 3).

Grafik 31851 Tarife Defterine Göre Osmanlı Devleti’nden Avusturya'ya İhraç Edilen Emtianın Dağılımı (Adet)

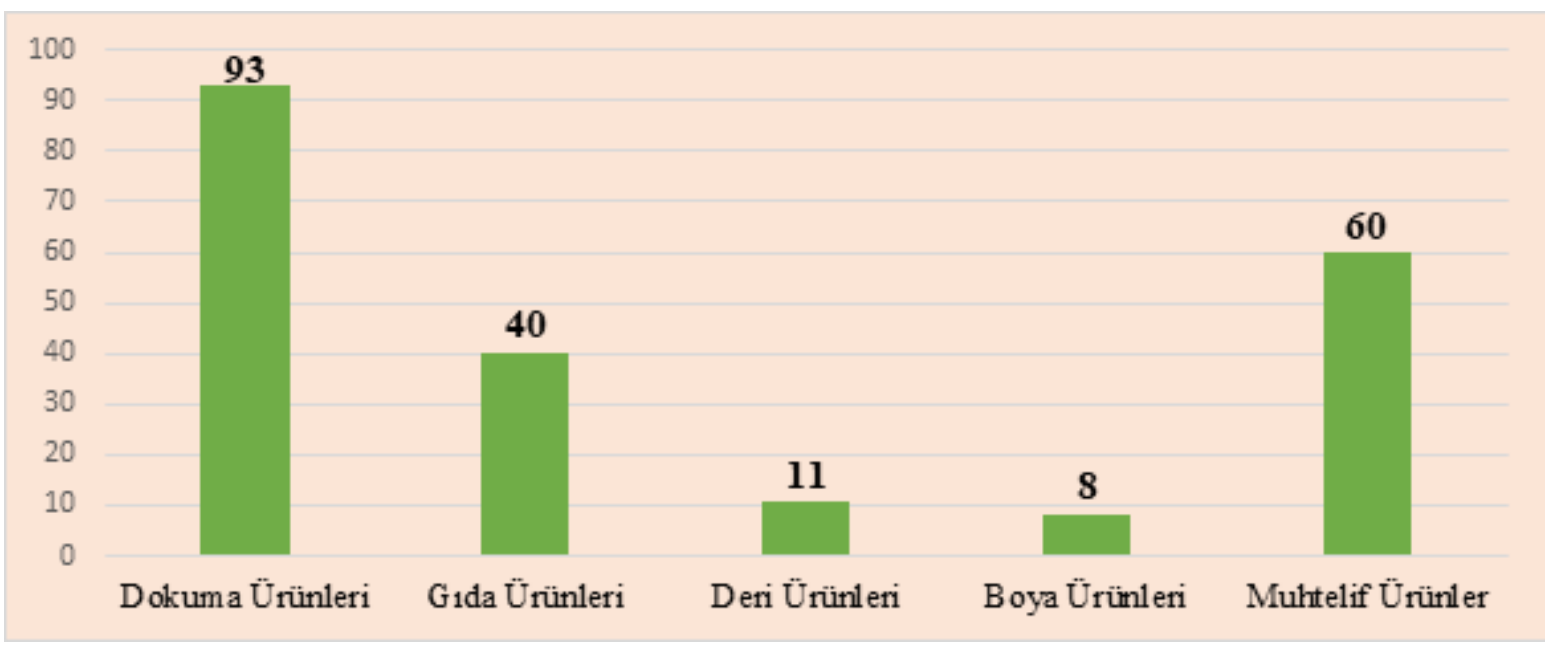

Kaynak: BOA, A.DVN.NMH, 39/18, s.1-34; 67/11 Numaralı Nemçe Ahkam Defteri, M.1839-1868/ H.1255-1285.s.144-173.

İlgili grafikte de gösterildiği üzere Osmanlı Devleti'nin ihraç ürünleri arasında dokuma ürünlerinin önemli bir paya sahip olduğu görülmektedir. İşlenmiş ve ham şekilde ticarete dâhil edilen bu mallar arasında; kirpas, elvan, harir, şal, sahtiyan, rişte, çit, basma yastık ve yorgan yüzleri, kutni, beledî, alaca, çitari ve çeşitli şehirlere ait kuşaklar yer almaktadır.

Gıda ürünlerine bakıldığında buğday, arpa, kokoroz ve çavdar gibi kuru bakliyatlar başta olmak üzere fındık, ceviz, pekmez, kuş üzümü, kuru üzüm, kimyon, pastırma, balık ürünleri ve mahlep dikkat çekmektedir. Deri ürünleri ticareti kapsamında da ekseriyetle keçi, koyun ve meşin derilerinin ihraç edildiği tespit edilmiş̧tir. Kök boya yapımında kullanılan mazı, kitre ve çividin de boya ticaretinde talep gören ürünlerin başında olduğu anlaşılmıştır. Belli bir grup altında toplanan bu ürünler dışında da envai kereste, sülük, sabun, neşter, sünger, güherçile, afyon, harnub ve zernih gibi mallar da ihracata konu olan muhtelif mallar içerisinde bulunmaktadır. Sonuç itibarıyla Osmanlı-Avusturya ticari ilişkileri bağlamında ithal ve ihraç edilen ürünlerin farklılık arz ettiğini söylemek gerekir. Zira her iki devlet de kendi ülkelerine ait zirâ̂, sanayi ve zanaat ürünlerinin işlenmiş ya da ham halini ticaretlerine dâhil etmiştir. Ayrıca Avusturya'nın Osmanlı Devleti'ne ihraç ettiği malların ekseriyetle mamul edilmiş mallardan oluştuğu anlaşılmaktadır. Diğer yandan Osmanlı Devleti'nin ihracatında ham ürünlerin daha baskın olduğu görülmüştür (Bkz: Ekler Tablo $1)$.

\section{Emtianın Vergilendirilmesi}

Osmanl1-Avusturya ticari ilişkilerine konu olan emtianın vergilendirilmesinde uygulamaya konan tarife muahedelerinin son derece önem arz ettiğini ifade etmek gerekmektedir. Zira tarifelerde ticarete dâhil olan emtiadan hangi oranda vergi alınacağı açık bir şekilde ifade edilmektedir. Bu bağlamda 1851 yılında yürürlüğe giren yeni tarifeye göre söz konusu iki devlet arasında husule gelen ticarette uygulanacak tarife oranının miktarı belirlenmiştir. Buna göre Avusturyalı tüccarların 
Osmanlı Devleti'ne ihraç edecekleri malların \% 3 üzerinden vergilendirilmesine karar verilmiştir. Ayrıca mezkûr tüccarların Osmanlı pazarlarından satın aldığı mallar da \% 9 amediye ve \% 3 reftiye olmak üzere toplamda \% 12 üzerinden vergilendirilmiştir. Öte yandan her iki devletin emtiası içerisinde rayice bırakılan ürünler de olmuştur (Bkz: Grafik 4).

Grafik 41851 Tarihli Tarife Defterine Göre Osmanlı-Avusturya Ticari İlişkilerine Konu Olan ve Rayice Bırakılan Ürünlerin Miktarı

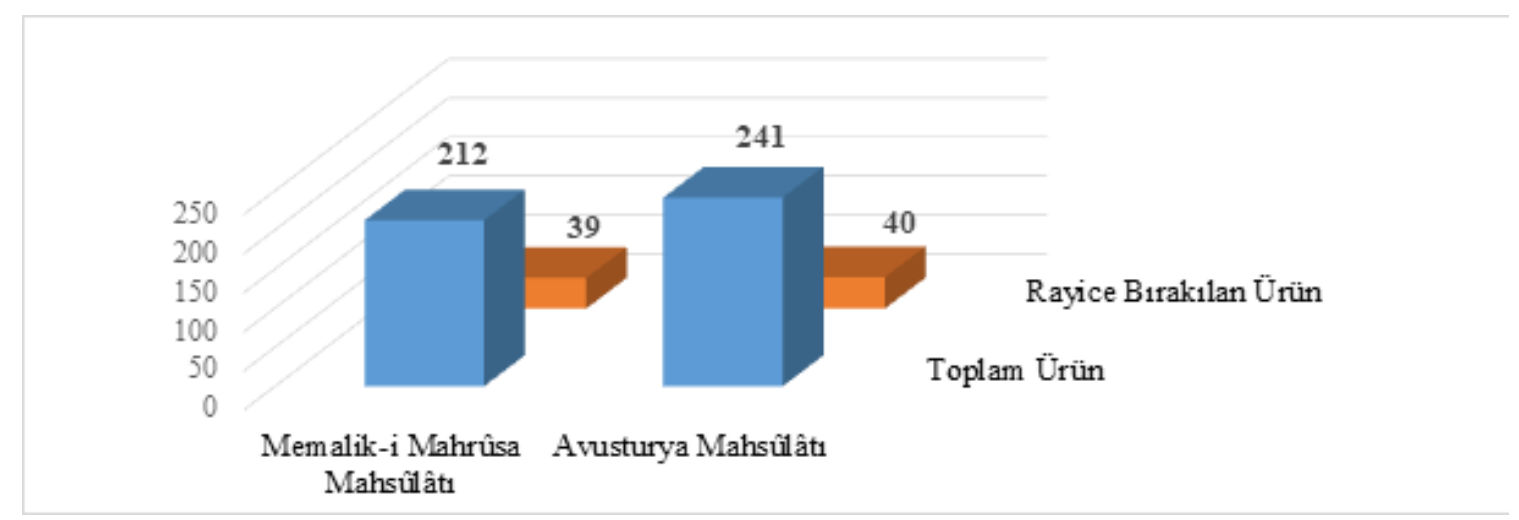

Kaynak: BOA, A.DVN.NMH, 39/18, s.1-34; 67/11 Numaralı Nemçe Ahkam Defteri, M.1839-1868/ H.1255-1285.s.144-173.

İlgili grafikte gösterildiği üzere Avusturya-Osmanlı devletlerinin mahsulatları içerisinde rayice bırakılan ürünlerin sayısının birbirine yakın olduğu görülmektedir. Avusturya mahsulatı içerisinde rayice bırakılan ürünlerin sayısı 40 olup, bu miktar da toplam ürünün \% 17'sine tekabül etmektedir. Rayice bırakılan Avusturya ürünleri arasında envaî hasır şapkalar, havlular, sepetler, sigara kâğıtları, şemsiye, kına, saat camı, çerçeveli ayna, kılıç, tüfek ve sair eşyalar yer almaktadır. Osmanlı Devleti (Memalik-i Mahrûsa), mahsulatına bakıldığında rayice bırakılan toplam ürün sayısı 39'dur. Toplam ürünün \% 18'e denk gelen bu ürünler, her nevi pastırma ve tuzlu et, helva, pekmez, pamuk, rişte, kereste, çivit, asfur, güherçile ve kuru bakliyattan oluşmaktadır (Bkz: Ekler Tablo 1 ve 2).

Ürünlerin rayice bırakılmasının esas nedeni “kıymet” kaidesine göre vergi dilimini doğru tespit ettirmektir. Aslında ürünün rayice bırakılması, tüccar ile gümrükçü arasında çoğu zaman ihtilafa neden olmaktır. Benzer sorunların da -sorunlar kısmında ifade edildiği gibi- Avusturyalı tüccarlar ile Osmanlı gümrük memurları arasında ortaya çıktığını ifade etmekte fayda vardır. Emtianın vergilendirilmesi hususunda rayice bırakılan ürünlerin dışında vergi miktarı belirlenen ürünler de bulunmaktadır. Bu ürünlerin vergi miktarlarının tespitinde bir takım usul ve kaidelerin etkili olduğunu söylemek gerekir. Bunlardan ilki ürünün vezin biçimidir. Buna göre Osmanl1-Avusturya devletleri mahsulatının miktarı ve vergisi tayin edilirken kullanılan ölçü birimlerinin arasında; tob, adet, kantar, miskal, çift, deste, kıyye, takım, sandık, zira', parça ve denk yer almaktadır. Bu ölçü birimleri, ağırlık ve ebatlarına göre farklılık göstermektedir. Mesela deri ürünleri, çorap, fes ve yün kalice gibi ürünler deste veya on iki adet şeklinde miktarı belirlenmiştir.

Yine envai mum ve boyalar kıyye üzerinden hesaplanmıştır. Ya da pastırma ve et çeşitleri kantar üzerinden ölçülmüştür. Örnekleri çoğaltmak mümkündür. Bundan dolayı her bir ürün, belli bir ölçü birimine göre miktarı belirlenmiş ve vergilendirilmeye tabi tutulmuştur. Öte yandan vergi 
miktarının tespit edilmesinde etkili olan bir diğer husus ise ürünün kıymeti ve kalitesidir (Işıktaş, 2020, s. 119). Bu minvalde ürünün kıymeti ve kalitesi yüksek olduğunda vergi miktarı da artış göstermektedir. Bu itibarladır ki Osmanlı-Avusturya ticari ilişkilerine yön veren 1851 tarihli yeni gümrük tarifesi, mezkûr hususlara bağlı olarak şekil almıştır. Yukarıda da ifade edildiği üzere Avusturya'dan Osmanlı Devleti'ne ihraç edilen mallardan \% 3'lük bir vergi alınmıştır. Mevzu bahis olan vergi oranı "akçe" üzerinden tespit edilmiştir. Ancak malın kıymeti, "kuruş ve para" cinsinden ifade edilmiştir. Bu doğrultuda her iki devlet için de ürün bazındaki vergi miktarları farkl11ık göstermiştir (Bkz: Grafik 5).

Grafik 51851 Tarihli Tarife Defterinde Yer Alan Avusturya Emtiasının Vergi Dilimi

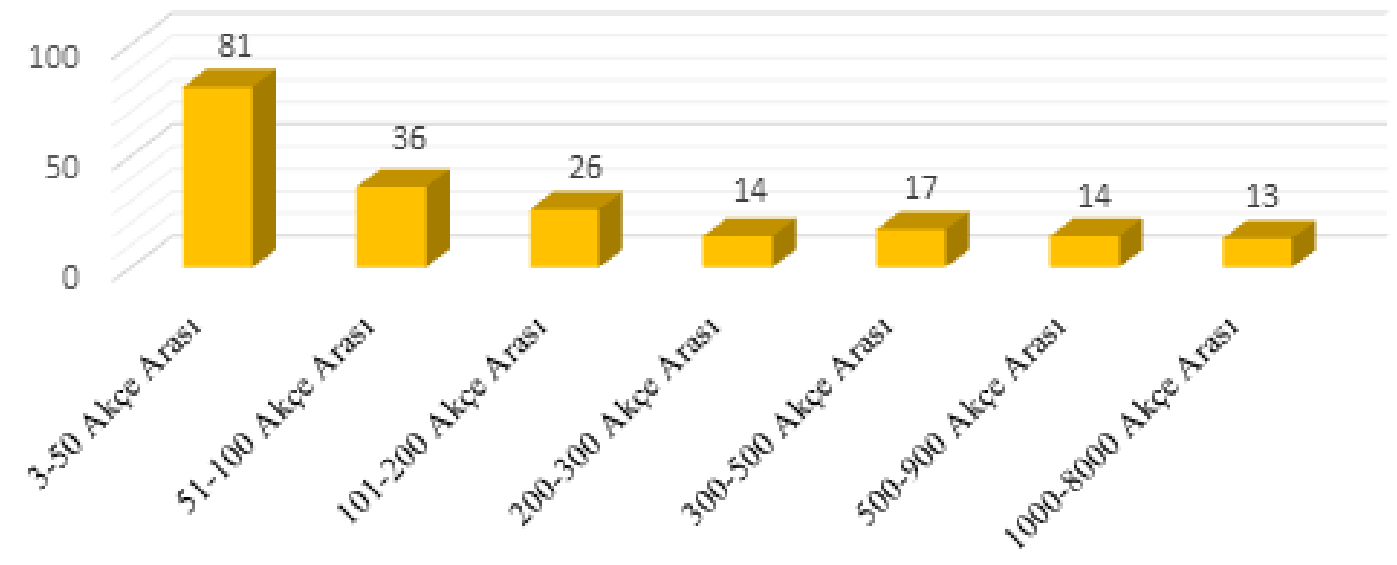

Kaynak: BOA, A.DVN.NMH, 39/18, s.1-34; 67/11 Numaralı Nemçe Ahkam Defteri, M.1839-1868/ H.1255-1285.s.144-173.

İlgili grafiğe göre, Avusturya'dan Osmanlı Devleti'ne ihraç edilen ürünlerin vergi aralıklarına bakıldığında yığılmanın 3 ile 50 akçe arasında olduğu görülmektedir. Diğer ürünlerin vergi dilimlerine oranla önemli bir paya sahip olan bu aralıkta, totalde 81 adet ürün yer almıştır. Akabinde kalan ürünlerin dağılımları incelendiğinde; 51-100 akçe arasında 36, 101-200 akçe arasında 26, 200-300 akçe arasında 14, 300-500 akçe arasında 17 ve 500-900 akçelik vergi dilimi aralığında 14 adet ürün bulunmaktadır. Bu vergi grubu içerisinde yer alan ürünlerin ekseriyeti, dokuma, hırdavat, mutfak, gıda ve diğer ürünlerden meydana gelmektedir. En yüksek vergi dilimi arasında ise 13 adet ürün yer almıştır. Bu ürünler de işlenmiş şem-i asel mumu, mercandan yapılmış tespihler, Avusturya mahsulü sahtiyan, kalay, Venedik ve Triste tahtasından oluşmaktadır. Öte yandan Avusturyalı tüccarların Osmanlı Devleti'nden satın aldıkları ürünlerin vergi aralıkları da değişkenlik göstermektedir (Bkz: Grafik 6). Bu vergi dilimleri aralığında yer alan ürünlerden -klymet esasına göre- \% 9 amediye ve $\% 3$ reftiye olmak üzere toplamda \% 12'lik bir vergi alınmıştır (Bkz: Ekler Tablo 1 ve 2). 
Grafik 61851 Tarihli Tarife Defterinde Yer Alan Osmanlı Devleti Emtiasının Vergi Dilimi Aralıkları (\% 9 Amediye ve \% 3 Reftiye)

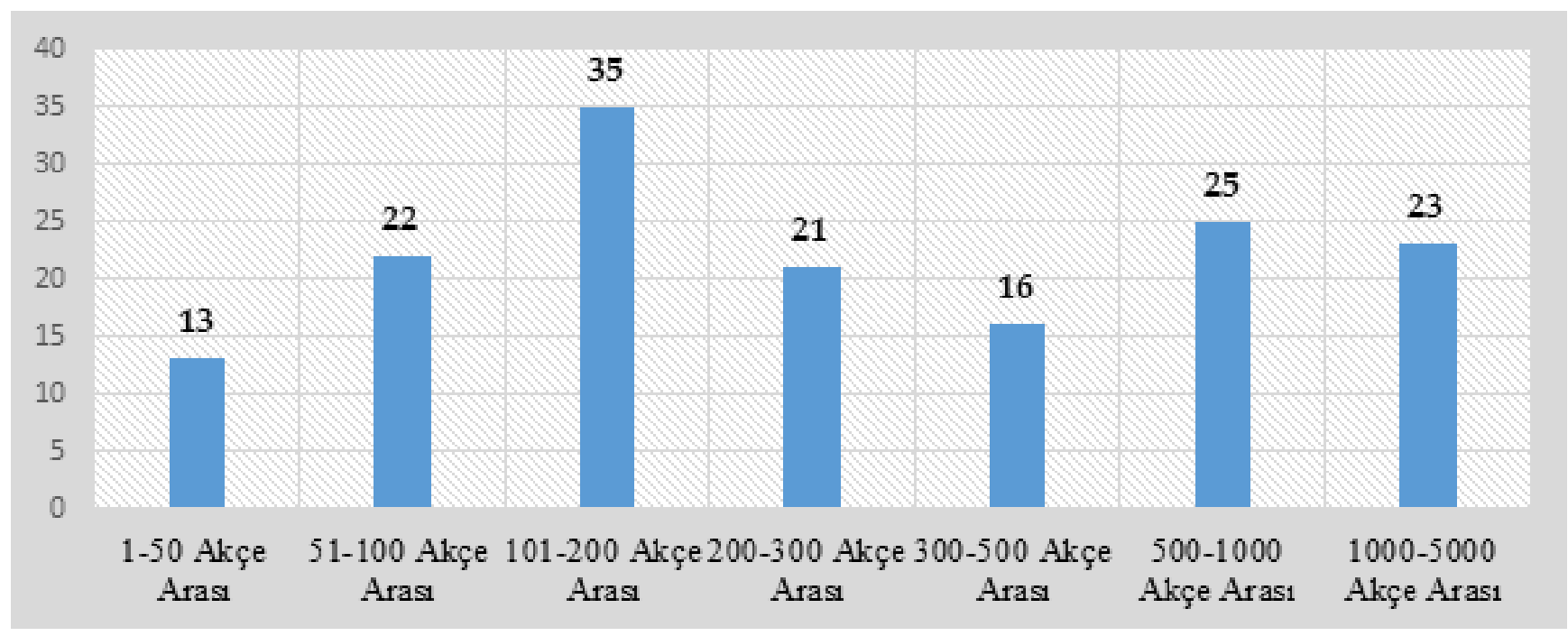

Kaynak: BOA, A.DVN.NMH, 39/18, s.1-34; 67/11 Numaralı Nemçe Ahkam Defteri, M.1839-1868/ H.1255-1285.s.144-173.

İlgili grafikte Avusturyalı tüccarların Osmanlı Devleti mahsulü sanayi, tarım ve zanaat ürünlerini kendi memleketlerine götürürken ödedikleri verginin ürün bazındaki dağılımları verilmiştir. Buna göre; 1-50 akçelik vergi dilimi arasında yer alan Osmanlı mahsulü ürünlerin diğer vergi dilimi aralıklarında yer alan ürün sayısına oranla daha az olduğu tespit edilmiştir. Hatta bu ürünler, aynı vergi dilimi aralığında yer alan Avusturya mahsulü ürünlerle de kıyaslandığında ürün niceliği bakımından oldukça düşük olduğu görülmektedir. Öte yandan en yüksek vergi dilimi içerisinde yer alan 1000-5000 akçelik aralıkta 23 adet ürün yer almıştır (Bkz: Ekler Tablo 1 ve 2).

Avusturyalı tüccarların Osmanlı Devleti’nden satın aldıkları ürünlerin en fazla yoğunlaştığı vergi dilimi aralığı 101 ile 200 akçe arası olmuştur. Bu vergi aralığında toplamda 35 adet ürün yer almıştır. Diğer dağılımlarına bakıldığında, 500-1000 akçe arasında 25, 300-500 akçe arasında 16, 200-300 akçe arasında 21 ve 51-100 akçelik vergi dilimi aralığında 22 adet ürün bulunmaktadır.

\section{Gümrükte Yaşanan Sorunlar}

Osmanlı-Avusturya gümrük ilişkilerinde ortaya çıkan sorunları birkaç konu başlığ 1 altında değerlendirmek mümkündür. Bunların başında yenilenmemiş tarifelerin doğurduğu aksaklık, tarifeden ziyade vergi alınması, çifte vergilendirme, gümrük idarecilerinin keyfi uygulamaları ve vergi mükellefiyetinden kaçmak isteyen Avusturyalı tüccarların tutumları yer almaktadır. Ne var ki bu sorunlar, irdelenen döneme has olmayıp, iki devlet arasındaki ticari ilişkilerde her dönem ortaya çıkan başat hususlar olmuştur.

Ele alınan dönem içerisinde, adları geçen iki devlet arasında en çok mülahaza edilen meselelerin başında "tarifeden ziyade vergi" alınması gelmiştir. Hakikaten bu problemin incelenen zaman dilimi aralığında ciddi bir miktarda artış gösterdiği de anlaşılmıştır. Tabi bunda eski tarifelerin güncellenememesinin etkili olduğu düşünülmektedir. Ayrıca gümrük idarecilerinin keyfi tutumları ile gümrük nizamına uygun hareket etmemeleri, tarifeden ziyade vergi alınma meselesinin daha da artmasına neden olmuştur. Öte yandan bu tür problemler karşısında Avusturyalı tüccarların 
müracaat etikleri ilk idari birim sefaretler olmuştur. Gümrükte haksızlığa uğrayan tüccar, ülkesini temsil eden ve haklarını korumakla görevli olan sefirler aracılığıyla meselenin hal olunmasını istemiştir.

Gerçekten de Osmanl1-Avusturya gümrük ilişkilerinde zuhura gelen sorunların çözümünde sefaretlerin eskiden beri önemli bir rol üstlendiklerini söylemek mümkündür. Mesela 22 Şaban 1230 tarihinde (30 Temmuz 1815) Halep eyaletinde ticari faaliyetlerini yürüten Avusturyalı tüccarların götürdükleri ve naklettikleri emtianın gümrük vergisi, mevcut tarife üzerinden ödemeleri meşru iken gümrük eminleri, Avusturyalı tüccarlardan fazla vergi talep etmeleri üzerine tartışma zuhur etmiştir. Konu ile ilgili Rusya elçisinin istidası üzerine Bâb-1 Âlî tarafindan Halep kadısı ve gümrükçüsüne hitaben bir yazı gönderilmiştir. Yazıda, düvel-i sâire tüccarının kendi memleketlerinden Halep'e götürdükleri emtia ve eşyadan \% 3 hesabıyla vergi alınması, mevcut tarife de yer almayan mallar var ise onların da rayiçleri üzerinden \% 3'lük dilime göre vergilendirilmesi ve fazla verginin alınmasına mani olunması istenmiştir ${ }^{36}$.

Gümrük ilişkilerine konu olan fazla vergi meselesinin yanı sıra zaman zaman çifte vergilendirme sorunu da zuhur etmekteydi. Esasen Osmanlı Devleti, eda tezkiresi ile bu tür problemlerin önüne geçebilmiştir. Ancak gümrük idarecilerinin keyfi tutumları çifte vergilendirme sorununun devam etmesine neden olmuştur. Buna benzer birçok sorun da Osmanl1-Avusturya gümrük ilişkilerinde husule gelmiştir. Örneğin Avusturya devleti tebaasından olan İnöz'de mukim Manol Cevani isimli tacir, satın almış olduğu çavdarları 2 rebiü'l-evvel 1260 tarihinde (22 Mart 1844) İnöz iskelesine naklederken mezkûr mahalde bulunan gümrükçü, tacirin elinde bulunan ve vergisini ödediğini gösteren meclis mazbatasına itibar etmemiş ve ikinci defa vergi talebinde bulunmuştur. Bunun üzerine kendisinden fazla vergi alınmasını uygun bulmayan tacir, bu durumu Avusturya Sefareti'ne bildirmiştir. Avusturya sefareti tarafından İnöz gümrükçüsüne hitaben yazılan emirnameyle iki defa gümrük vergisi istenmeyerek çavdarın çıkışına ruhsat verilmesi talep edilmiştir ${ }^{37}$.

Gümrük sorunları kapsamında değerlendirebilecek diğer bir husus ise malların tevkif edilmesi ya da alıkonulmasıydı. Bu uygulama, çoğu zaman kaçak veya zararlı mallar için hayata geçiriliyordu. Ancak gümrükçü ile tacir arasında meydana gelen tartışmalar neticesinde de zaman zaman mallara ele konulabilirdi. Bu durum da gümrükçünün ya malı ucuza alma ya da rüşvet alma hareketlerinin bir tezahürü olarak yansımaktaydı. Mesela Avusturyalı tüccar Karamero Karanikod Dinalik'in mallarını İzmir gümrüğünden geçirirken, vergi tayini hususunda gümrükçüyle yaşadığı tartışma neticesinde malları tevkif edilmiştir. Meselenin sefaret aracılığıyla Bab-1 Âli'ye bildirilmesi üzerine 1 Muharrem 1263 tarihinde (20 Aralık 1846) İzmir gümrüğüne hitaben bir emirname gönderilmiştir. Buna göre; İzmir gümrügünden, tacirden fazla alınan verginin iadesi, İzmir'e götürdügü ve oradan satın aldığı emtianın gümrük vergisinin eski tarife üzerinden hesaplanması istemiştir ${ }^{38}$.

Fazla vergi probleminin yaşandığı bir diğer mahal Bosna eyaleti olmuştur. Bu bağlamda 14 Şevval 1262 tarihinde (5 Ekim 1846) Avusturya Sefareti tarafından kaleme alınan bir yazıda; Avusturyalı tüccarların Bosna eyaletine getirdikleri ve oradan satın alıp kendi memleketlerine

\footnotetext{
36 BOA, C.HR, 152/7566, 30 Temmuz 1815/22 Şaban 1230.

37 BOA, HR.MKT, 2/75, 22 Mart 1844/2 Rebiü'l-evvel 1260.

38 BOA, A.MKT, 59/2, 20 Aralık 1846/1 Muharrem 1263.
} 
götürdükleri emtiadan Bosna gümrük mültezimi Mustafa Paşa'nın gümrük nizamına aykırı olarak fazla vergi tahsil etmekte olduğuna ilişkin bilgiler yer almaktadır. Ayrıca \% 3 'ten fazla alınmış olan verginin derhal sahiplerine teslim edilmesi talep edilmiştir ${ }^{39}$. Bunun üzerine 23 Şevval 1262 tarihinde (14 Ekim 1846) Hariciye Nezareti Mektubî Kalemi’nden Bosna valisine hitaben gönderilen yazıda, Avusturyalı tüccarların Bosna ve Hersek, Eflak ve Boğdan eyaletlerine götürdükleri ve oradan satın aldıkları emtia ve eşyadan eski tarifeye göre gümrük vergisinin tahsil edilmesi istenmiştir. Bununla birlikte Bosna gümrük mültezimi Mustafa Paşa'nın nizama aykırı bir şekilde tahsil etmiş olduğu fazla verginin derhal sahiplerine iadesi talep edilmiştir ${ }^{40}$.

$\mathrm{Bu}$ noktada Bosna eyaletine ayrı bir parantez açmakta fayda vardır. Zira incelenen dönemde gümrük memurları ile Avusturyalı tacirler arasında bu tür problemlerin bir hayli fazla olduğu görülmüştür. Bilhassa Bosna gümrük mültezimi Mustafa Paşa, gümrük nizamına aykırı davranışlarıyla dikkat çekmiştir. Bundan ötürü Avusturya sefareti, gümrük mülteziminin tüccardan fazla gümrük vergisi talebinin engellenmesine ilişkin çeşitli yazılar yazmıştır ${ }^{41}$.

Hakeza mesele, Osmanlı idari mercileri tarafından incelenmeye alınmıştır. 27 Cemaziyelevvel 1263 tarihinde (13 Mayıs 1847) Meclis-i Vala'da; Avusturyalı tüccarlardan alınan fazla vergi meselesi ele alınmıştır. Adı geçen meclis tarafından hazırlanan mazbatada; Avusturyalı tüccarların Bosna eyaletine getirdikleri ve oradan satın aldıkları malların vergisi \% 3 üzerinden hesaplanmasına işaret edilmiştir ${ }^{42}$. 9 Cemaziyel-ahir 1263 tarihli (25 Mayıs 1847) başka bir yazıda da Bosna eyaletinde ticari faaliyetlerini yürüten Avusturyalı tüccarlardan \% 3 'ten fazla vergi alınmaması ve gümrük işlerinde muktedir yeni bir memurun tayin edilmesi gerektiği ifade edilmiştir ${ }^{43}$. Öte yandan 1847 yılında Avusturya Sefareti tarafindan verilen takrirde gümrük memurlarının Avusturyalı tüccarlardan fazla vergi talebinin engellenmesi istenmiştir ${ }^{44}$.

1847 yılında Osmanlı-Avusturya ticari ilişkilerinde vergi problemleri artması üzerine Avusturya Elçisi Kont Astormar tarafından Sefaret Baştercümanı Baron Testa'ya bir talimatname verilmiştir. Talimatnamede, vergi tayini noktasında gümrükçü ile tüccar arasında malın kıymetinin belirlenmesi hususunda anlaşmazlıklara dikkat çekilmiş ve temel nedenleri izah edilmeye çalışılmıştır. Özellikle Osmanlı-Avusturya devletleri arasındaki gümrük nizamına göre malın gümrüğe gelişindeki değeri ne kadar ise gümrük vergisinin ona göre belirlenmesi gerektiğine vurgu yapılmıştır. Bu noktada Avusturyalı tüccarların iddialarına da yer verilen talimatnamede Osmanlı gümrük memurlarının keyfiyetleri nazarınca hareket ettiklerine dair bilgiler bulunmaktadır. $\mathrm{Bu}$ bağlamda Avusturya sefaretinin Hariciye Nezareti'nden istirhamı, tarife ahkâmına uygun olarak tüccarların iskeleye getirdikleri malların kıymeti belirlendikten sonra \% 3 üzerinden verginin tespit edilmesi olmuştur. Zira tüccarın getirmiş olduğu emtia, gümrüğe getirilip satılana kadar vuku bulan masrafın \% 25'ten fazla olduğu ve bunun dikkate alınarak verginin belirlenmesi gerektiğine dikkat çekilmiştir ${ }^{45}$. 
Osmanlı Devleti ile Avusturya sefareti arasındaki diplomatik görüşmelere rağmen gümrük merkezlerinde meydana gelen problemlere nihai bir çözüm getirilememiştir. Özellikle tarife meselesinden ötürü farklı gümrük merkezlerinde gümrükçü ile tüccar arasındaki tartışmalar devam etmiştir. Yine Bosna örneğinden hareket edilirse 1848 yılında Avusturyalı tüccarların Bosna'ya götürdükleri emtia ve eşyadan \% 3 oranında bir vergi alınması gerekirken fazla vergi alındığına dair şikâyetler, Avusturya Sefaretinden bildirilmiştir. Buna göre; Bosna eyaletinde Gradçaniça kazasında Berud (?) iskelesine tabi Jopan (?) gümrüğüne giden İsmail Ronestayn isimli tüccar, elinde eda tezkiresi olmasına rağmen ithal ettiği bazı mallar için \% 13 oranında vergi vermek zorunda kalmıştır. Bundan dolayı sefaretçe, fazla alınan verginin mezkûr tacire verilmesi ve bundan böyle nizama aykırı davranılmamasını istirham edilmiştir ${ }^{46}$. Bunun üzerine 20 Şevval 1264 (19 Eylül 1848) senesinde Bosna Valisine gönderilen yazıda; Bosna Eyaleti, Hersek sancağı Eflak ve Boğdan havalisine gelen Avusturyalı tüccarlardan yüzde üçten fazla vergi alınmaması ve muahedat-1 atik ahkâmına uygun olarak gümrük muamelatlarının yapılması istenmiştir. Bu bağlamda Bosna eyaletindeki gümrük memurlarının buna ehemmiyet göstermeleri talep edilmiştir ${ }^{47}$.

Tarifeden ziyade vergi probleminin yaşandığı bir diğer mahal ise Cezayir olmuştur. Avusturyalı tüccar Mardevic (?), Triste bölgesine götürdüğü üzümler için tarifeden ziyade vergi tahsil edilmesi üzerine Avusturya sefaretine başvurmuştur. Bunun üzerine sefaretçe hazırlanan arzuhalle, 1846 senesinde mezkûr tacirin İstanköy'de satın aldığı beş yüz kantar üzüme tarifeden ziyade tahsil edilmiş olan bin yedi yüz on iki buçuk kuruşun iadesi talep edilmiştir. Ayrıca Cezayir gümrügünde husule gelen ziyade vergi alınmasına ilişkin meselenin araştırılması istenmiştir. $\mathrm{Bu}$ bağlamda Osmanlı idari birimlerince yapılan tahkikatta bölgede faaliyet gösteren düvel-i sâire tüccarları ile Cezayir gümrükçüsü beyninde vergi tayini meselesinden ötürü benzer şikâyetlerin devam ettiği görülmüştür. Hatta bu problemlerin zuhurunda yenilenemeyen tarifelerin mühim bir rol oynadığı anlaşılmıştır. Bu nedenledir ki Cezayir-i Bahr-i Sefid valisine gönderilen tahriratta, gümrükte görev yapan idarecilerin yeni tarife yapılana kadar daha önce belirlenmiş olan usul ve kaidelere göre gümrük işlemlerinin yapılması istenmiştir. Ayrıca söz konusu tacirden alınmış olan fazla verginin Cezayir gümrük hazinesinden ödenmesi istenmişse de, aradan üç y1l geçmesine rağmen ödeme yapılmamıştır. Bu doğrultuda 10 Cemaziyel-ahir 1266 (23 Nisan 1850) tarihinde Hariciye Nezareti'nden Cezayir-i Bahr-i Sefid valisine yazılan yazıyla mezkûr tacirden fazla alınmış olan meblağın iadesi talep edilmiştir ${ }^{48}$.

Netice itibarıyla vergi tayini hususunda ortaya çıkan sorunları çözmek için Osmanl1Avusturya devletlerinin göstermiş oldukları tutum ve gayretlerine rağmen bu problemlerin önünün alınamadığı anlaşılmaktadır. Osmanlı Devleti, merkez ve taşra idarecilerine göndermiş olduğu emirnamelerle gümrük memurların nizama uygun bir şekilde hareket etmelerini istemiştir. Ancak mültezimlerle memurların keyfi davranışları ve eski tarifelerin yenilenememesi, meselenin halledilmesini geciktirmiştir. Haddizatında Avusturya sefareti, kendi tebaa tüccarlarının haklarını koruma ve gümrük nizamına uygun bir şekilde ticari faaliyetlerini yürütmeleri noktasında Osmanlı Devleti ile sürekli iltimas içinde olmuş, husule gelen meselelerin çözülmesi için arzuhaller kaleme almıştır. Nitekim tarife problemlerinin ilerleyen dönemlerde de devam ettiği tartışılmaz bir gerçek olarak tarihteki yerini almıştır. 


\section{Sonuç}

Tarihte siyasi ve askeri bağlamda yakın bir ilişki içerisine giren Osmanl1-Avusturya devletlerinin ticari faaliyetleri de oldukça dikkat çekici olmuştur. 16. yüzyılda mikro ölçekte başlayan ticari ilişkiler, zamanla kayda değer bir oranda artış göstermiştir. Tabi bunda, ticari ilişkilerin hukuksal zeminini teşkil eden imtiyaz fermanları, ahidnameler ve antlaşmaların büyük bir etkisi olmuştur. Bu yasal metinlerde yer alan ticari prosedürlerde iki devlet arasındaki ticarete konu olan emtiaya uygulanacak olan gümrük muamelatına ilişkin kıymetli bilgiler bulunmaktadır.

Araştırmada; incelenen dönem içerisinde Osmanl1-Avusturya ticari ilişkilerine mevzu bahis olan hususların başında tarife meselesinin geldiği anlaşılmıştır. 1832-1851 yılları arasında 1818 tarihli eski tarifenin güncellenmesi meselesi sürekli gündemde olmuş, aradan geçen on dokuz yıllık süre zarfında tarifenin yenilenemediği tartışılmaz bir sonuç olarak karşımıza çıkmıştır. Bu süreç içerisinde Osmanlı Devleti, 1839 senesinde almış olduğu kararla Avusturyalı tüccarların ticari faaliyetlerine uygulanan gümrük muamelatını, diğer Avrupalı tüccarlara uygulanan muamelatla eşit tutmuştur. Osmanlı Devleti'nin bu kararını iki hususta açıklamak gerekmektedir. Bunlardan ilki gümrük gelirlerinde husule gelecek gelir kaybını giderme düşüncesidir. Diğeri ise gümrük merkezlerinde yaşanan sorunları minimize etmektir.

1838 senesinde Osmanl-İngiltere arasında yapılan ticaret antlaşmasıyla Osmanlı gümrük nizamı ciddi değişikliklere maruz kalmıştır. Böylece diğer devletlerin tüccarların da olduğu gibi Avusturyalı tüccarlar da Osmanlı pazarlarından götürecekleri emtialar için \% 9 amediye ve \% 3 reftiye vergisine tabi tutulmuştur. Ayrıca Avusturyalı tüccarların Osmanlı'ya getireceği mallar da kıymetleri üzerinden \% 3'lük bir dilimle vergilendirilmiştir. Nitekim Osmanlı-Avusturya arasında uygulamaya konulan bu tarifelerin iki devlet arasında uygun bulunan bir ahidname neticesinde oluşmamış, Balta Limanı Ticaret Antlaşması'nın bir dayatması olarak ortaya çıkmıştır.

Ticari ilişkilerde uygulanan eski tarifenin yenilenmesine yönelik, iki devletin de azami ölçüde hassasiyet gösterdiğini söylemek mümkündür. Ancak siyasi şartların bu meseleyi ertelediği görülmüştür. Bu bağlamda Osmanlı Devleti, tarife müzakerelerinin yapılmasına yönelik çalışmalarını yürüttüğü esnada baş gösteren 1848 ihtilalleri neticesinde yalnızca Avusturya değil diğer Avrupalı devletlerle de tarifelerin yenilenemediği sonucuna ulaşılmıştır. Akabinde geçen üç yılın ardından tarifeler güncellenebilmiştir.

1851 tarihli tarife, Osmanl1-Avusturya ilişkilerini yeniden tertiplemesi ve husule gelen gümrük sorunlarını ortadan kaldırmayı amaçlaması bakımından oldukça önemli olduğu anlaşılmıştır. Bu bağlamda ticarete konu olan emtiadan alınacak olan vergi miktarı yasal çerçevede tespit edilmiştir. Böylece tacirlerin, Osmanlı Devleti'ne getirdikleri mallar \% 3, Osmanlı topraklarından götürdükleri eşyalar \% 9 amediye ve \% 3 reftiye üzerinden vergilendirilmiştir. Malların kıymet bakımından değerleri kuruş olarak hesaplanırken vergi miktarının akçe para birimine göre tayin edildiği; ayrıca rayice bırakılan ürünlerin de azımsanmayacak bir orana sahip olduğu görülmüştür. İlgili tarifeden hareketle Osmanl-Avusturya ticaretine konu olan malların ekseriyetle dokuma ve giyim malzemesi, gıda maddeleri, mutfak araç-gereçleri, ağaç ürünleri, hırdavat ve muhtelif eşyalardan oluştuğu anlaşılmıştır.

Osmanl1-Avusturya gümrük ilişkilerinde, tarifeden ziyade vergi alınması ve çifte vergilendirme meselelerinin en çok tartışılan hususların başında geldiği görülmüştür. Bu meselenin çözülememesinin temel nedeni tecdit edilmemiş tarifelerin doğurduğu aksaklıktan kaynaklandığı 
anlaşılmıştır. Hatta söz konusu sorunların önceki dönemlerde de sürekli gündemde olduğu dikkate alındığında meselenin güncelliğini koruduğunu, gümrükçü ile tüccar arasında benzer sorunların devam ettiğini göstermektedir. Öte yandan bu tür problemler karşısında aciz kalan tüccarlar, çözümü sefaret merkezinde aramış meselenin diplomatik kanallarla halledilmesi yoluna başvurmuştur.

\section{Kaynaklar}

TC Cumhurbaşkanlığı Devlet Arşivleri Başkanlığı (BOA)

A. \{DVNSDVE.d (Divan-1 Hümâyûn Sicilleri Düvel-i Ecnebiye Defterleri), 67/11 Numaralı Nemçe Ahkam Defteri, M.1839-1868/ H.1255-1285.

A.\}DVN.NMH (Sadâret Nâme-i Hümâyûn Evrak1), 39/18, 25 Ekim 1851/29 Zilhicce 1267.

A.\}MKT (Bâb-1 Âsafî Mektubî Kalemi), 149/27, 19 Eylül 1848/20 Şevval 1264.

A.\}MKT (Bâb-1 Âsafî Mektubî Kalemi), 19/78, 9 Ocak 1845/29 Zilhicce 1260.

A.\}MKT (Bâb-1 Âsafî Mektubî Kalemi), 126/53, 9 Mayıs 1848/ 5 Cemaziyelahir 1264.

A.\}MKT (Bâb-1 Âsafî Mektubî Kalemi), 59/2, 20 Aralık 1846/1 Muharrem 1263.

A.\}MKT (Bâb-1 Âsafî Mektubî Kalemi), 59/28, 1 Mayıs 1846/5 Cemaziyelevvel 1262.

A.\}MKT (Bâb-1 Âsafî Mektubî Kalemi), 75/19, 5 Nisan 1847/18 Rebiülahir 1263.

A.\}MKT (Bâb-1 Âsafî Mektubî Kalemi), 82/68, 25 Mayıs 1847/9 Cemaziyelahir 1263.

A.\}MKT.MVL (Sadâret Mektubî Kalemi Meclisi Vala Evrak1), 5/17, 9 Mayıs 1847/23 Cemaziyelevvel 1263.

C.HR (Cevdet Hariciye), 133/6621, 30 Nisan 1818/23 Cemaziyelahir 1233.

C.HR (Cevdet Hariciye), 152/7566, 30 Temmuz 1815/22 Şaban 1230.

C.HR (Cevdet Hariciye), 54/2661, 23 Nisan 1850/10 Cemaziyelahir 1266.

C.HR (Cevdet Hariciye), C.HR, 41/7033, 28 Kasim 1818/29 Muharrem 1234

HAT (Hatt-1 Hümâyûn), 961/41195, 28 Nisan 1835/29 Zilhicce 1250.

HR.MKT (Hariciye Nezareti Mektubî Kalemi), 14/16, 5 Ekim 1846/14 Şevval 1262.

HR.MKT (Hariciye Nezareti Mektubî Kalemi), 2/75, 22 Mart 1844/2 Rebiü'l-evvel 1260.

HR.TO (Hariciye Tercüme Odas1), 150/38, 9 Kasım 1847/30 Zilkade 1263.

HR.TO (Hariciye Tercüme Odas1), 567/72, 14 Ağustos 1847/2 Ramazan 1263.

İ.MSM (Mesail-i Mühimme), 34/963, 14 Haziran 1848/12 Receb 1264.

MFB (Müzehhep Ferman ve Beratlar), 1325, 24 Kasım 1846/5 Zilhicce 1262.

\section{Araştırma ve İnceleme Eserler}

Atan, Turhan, Türk Gümrük Tarihi II, Ata Ofset Matbaacılık, İstanbul 1995.

Bağış A. İhsan, Osmanlı Ticaretinde Gayrimüslimler, Turhan Kitapevi, Ankara 1983.

Beydilli, Kemal, Avusturya. Türkiye Diyanet Vakfi Islam Ansiklopedisi, Cilt 4, Türkiye 
Diyanet Vakfı Yayınları, İstanbul 1991, s.174-177.

Bozkurt, Nurgül, "XVIII. Yüzyılın Başlarında Osmanl1-Avusturya Ticari Münasebetleri”, Tarih Incelemeleri Dergisi, Cilt 12, Say1 1, 1997, s.183-196.

Bozkurt, Nurgül, Osmanlı Arşiv Belgelerine Göre Osmanlı - Avusturya münasebetleri: 17401788, (Yayınlanmamış Doktora Tezi), Süleyman Demirel Üniversitesi, Sosyal Bilimler Enstitüsü, Tarih Anabilim Dalı, Isparta 2000.

David, Geza, "XVI. Yüzyılda Osmanl1-Habsburg Mücadelesinin Bir Kaynağı Olarak Mühimme Defterleri”, Tarih Dergisi, Sayı 53, İstanbul 2012, s.295-349.

Elibol, Numan, XVIII. Yüzyılda Osmanlı-Avusturya Ticareti, (Yayınlanmamış yüksek lisans tezi) Marmara Üniversitesi, Türkiyat Araştırmaları Enstitüsü Yeniçă̆ Tarihi Bilim Dalı, İstanbul 2003.

Emecen, M. Feridun, "Çağdaş Osmanlı Kaynaklarında Uzun Savaşlar ve Zitvatorok Antlaşması İle İlgili Algılama ve Yorumlama Problemleri”, Osmanlı Araştırmaları Dergisi, Cilt XXIX, İstanbul, 2007, s. 87-97.

Genç, Mehmet, Osmanlı'da Devlet ve Ekonomi, Ötüken Neşriyat, İstanbul 2014.

Gürsel, Seyfettin, “1838 Osmanl1-İngiliz Ticaret Antlaşması”, Tanzimat'tan Cumhuriyet'e Türkiye Ansiklopedisi, Cilt 3, İletişim Yayınları, İstanbul 1985, s.688-691.

Işıktaş, Erkan, “5249 Numaralı Gümrük Tarife Defterine Göre Diyarbakır Gümrügüne Getirilen Emtialar: Emtianın Cinsi, Vergisi ve Emtia-Fiyat İlişkisi”, Yüzüncü Yıl Üniversitesi Sosyal Bilimler Enstitüsü Dergisi, Sayı 50, 2020, s.109-141.

İzgüer, A. Zeki, “Osmanlı İmparatorluğu Tarafından Avusturya’ya Verilen Ticari İmtiyazlara Dair”, Türk Dünyası Araştırmaları Dergisi, Sayı 59, 1989, s.75-86.

Kolçak, Özgür, “XVII. Yüzyıl Osmanl1-Habsburg Diplomasi Tarihine Bir Katk1: 1664 Vasvar Antlaşması'nın Tasdik Sürecine Dair Yeni Bulgular”, Dîvân Disiplinlerarası Çalışmalar Dergisi, Cilt XXII, Say1 43, 2017, s. 25-88.

Kurdakul, Necdet, “Ticaret Antlaşmaları”, Tanzimat'tan Cumhuriyet'e Türkiye Ansiklopedisi, Cilt 3, İletişim Yayınları, İstanbul 1985, s.666-668.

Kurtaran, Uğur, "XVIII. Yüzyılda Osmanlı Devleti İle Avusturya Arasındaki Ticaret Antlaşmaları ve Yaşanan Değişimler”, Hitit Üniversitesi Sosyal Bilimler Enstitüsü Dergisi, Sayı 9, Cilt 2, Aralık 2016, s.743-769.

Küçükkalay, A. Mesud - Elibol Numan, “Osmanlı İmparatorluğu’na Avrupa'dan Karayolu ile Yapılan İhracatın Değerlendirilmesi: 1795-1804”, Osmangazi Üniversitesi Sosyal Bilimler Dergisi, Sayı 2, 2003, s.151-176.

Kütükoğlu S. Mübahat, “Osmanlılarda Gümrük”, Türkiye Diyanet Vakfi İslam Ansiklopedisi, Cilt14, Türkiye Diyanet Vakfı Yayınları, İstanbul 1996, 263-268.

Kütükoğlu, S. Mübahat, Balta Limanına Giden Yol Osmanll-Ingiliz İktisadi Münasebetleri (1580-1850), Türk Tarih Kurumu Yayınlar, Ankara 2013.

Mardin, Şerif, “Tanzimat’tan Cumhuriyete İktisadi Düşüncenin Gelişmesi (1838-1918)”, 
Tanzimat'tan Cumhuriyet'e Türkiye Ansiklopedisi, Cilt 3, İletişim Yayınları, İstanbul 1985, s.618634.

Odor, Pal, "Macaristan'a Yönelik Osmanlı Siyaseti, 1520-1541”, Cilt 40, Sayı 40, Tarih Dergisi, 2004, s. 11-86.

Özkan, Selim Hilmi, "Karlofça Antlaşması Sonrası Osmanlı Avusturya İlişkilerinde Macarların Durumu", Avrasya Etütleri, Sayı.41, 2012, s.183-195.

Sándor, Papp, “Zitvatorok Antlaşması”, Türkiye Diyanet Vakfi İslam Ansiklopedisi, Cilt 44, Türkiye Diyanet Vakfı Yayınları, İstanbul 2013, s.472-474.

Uğur Kurtaran, "XVIII. Yüzyıl Osmanlı Avusturya Siyasi İlişkileri”, Tarih Okulu Dergisi (TOD), Sayı XVII, 2014, s.393-419.

Uzunçarşılı, İ. Hakkı, Osmanlı Tarihi, (II) Türk Tarih Kurumu Yayınları, Ankara 2016.

Yeniçeri, Celal, "Bâc", Türkiye Diyanet Vakfi İslam Ansiklopedisi, Cilt 4, Türkiye Diyanet Vakfi Yayınları, İstanbul 1991, s.411-413. 


\section{Ekler}

Tablo 11851 Tarihli Tarife Defterinde Yer Alan Osmanlı Devleti Ürünleri (Örnek)

\begin{tabular}{|c|c|c|c|c|c|}
\hline \multirow[b]{2}{*}{ Emtianın Cinsi } & \multirow[b]{2}{*}{ Vezni ve Miktarı } & \multicolumn{2}{|c|}{ Kiymeti } & \multirow{2}{*}{$\begin{array}{c}\text { Amediye } \\
\text { Vergisi } \\
\% 9 \\
\text { (Akçe) }\end{array}$} & \multirow{2}{*}{$\begin{array}{c}\text { Reftiye Vergisi } \\
\% 3 \\
\text { (Akçe) } \\
\end{array}$} \\
\hline & & Kuruş & Para & & \\
\hline Arak & Kiyye (1) & 3 & 30 & 24 & 11 \\
\hline İ̆gne & Kiyye (1) & 12 & 00 & 109 & 36 \\
\hline Alaca Haleb & Tob (1) & 30 & 00 & 272 & 90 \\
\hline Alaca-i Şam ve çitari ve kitâbi & Tob (1) & 60 & 00 & 544 & 181 \\
\hline Alaca-i Manisa & Tob (1), Denk (1) & 900 & 00 & 8165 & 2721,5 \\
\hline Alaca-i tire ve bor & Tob (1) & 8 & 00 & 72 & 24 \\
\hline Kök Boya Anadolu & Kantar (1) & 175 & 00 & 1588 & 529 \\
\hline Kök boya Kıbrıs ve Şam ve Trablusgarp & Kantar (1) & 98 & 20 & 885 & 295 \\
\hline Enison (?) Kayseriye & Kiyye (1) & 2 & 30 & 25 & 8 \\
\hline Enison Rumeli & Kiyye (1) & 2 & 10 & 20 & 6 \\
\hline Alef (?) & Rayicinden & - & - & $\% 9$ & $\% 3$ \\
\hline Kamçıbaşı ve kuzu & Rayicinden & - & - & $\% 9$ & $\% 3$ \\
\hline Elvan & Kiyye (1) & 18 & 00 & 136 & 54 \\
\hline Bulama ve helva & Rayicinden & - & - & $\% 9$ & $\% 3$ \\
\hline Roğan sade & Rayicinden & - & - & $\% 9$ & $\% 3$ \\
\hline Balık Yumurtası & Rayicinden & - & - & $\% 9$ & $\% 3$ \\
\hline Kahve-yi yemen Misır'dan gelen & Kiyye (1) & 7 & 20 & 68 & 22 \\
\hline Şema' roğan ve mamul şema' asel & Rayicinden & - & - & $\% 9$ & $\% 3$ \\
\hline Bilcümle bastırma ve tuzlu et & Rayicinden & - & - & $\% 9$ & $\% 3$ \\
\hline Harnub & Rayicinden & - & - & $\% 9$ & $\% 3$ \\
\hline Şema’ asel külçe & Kiyye (1) & 19 & 00 & 173 & 57 \\
\hline Çitari-i Şam & Tob (1) & 60 & 00 & 544 & 181 \\
\hline Beyaz ve elvan karacalar kuşağı & Kiyye (1) & 17 & 00 & 154 & 51,5 \\
\hline Ham kuşağ1 & Adet (1) & 9 & 00 & 81 & 27 \\
\hline Kuşak & Adet (1) & 50 & 00 & 454 & 151 \\
\hline İplik şerbab kuşağ1 & Adet (1) & 20 & 00 & 181 & 60 \\
\hline Harirli şerbab kuşağı & Adet (1) & 35 & 00 & 318 & 106 \\
\hline Harirden Trablus kuşağı & Kiyye (1) & 200 & 00 & 1814 & 605 \\
\hline Kuşak Tunus & Adet (1) & 40 & 00 & 363 & 121 \\
\hline Ebucehil kapuzu & Kiyye (1) & 10 & 00 & 91 & 30 \\
\hline Kehribar & Kiyye (1) & 2 & 00 & 18 & 6 \\
\hline Kimyon & Kiyye (1) & 2 & 10 & 20 & 6,5 \\
\hline Manda boynuzu & Çift (100) & 260 & 00 & 1180 & 363 \\
\hline Geyik boynuzu & Kiyye (1) & 5 & 00 & 45 & 15 \\
\hline
\end{tabular}




\begin{tabular}{|c|c|c|c|c|c|}
\hline Misir'dan gelen penbe-i hind & Rayicinden & - & - & $\% 9$ & $\% 3$ \\
\hline Bil-cümle pembe-i Anadolu & Kantar (1) & 236 & 20 & 2145 & 715 \\
\hline Penbe-i ham Misır ve Şam & Rayicinden & - & - & $\% 9$ & $\% 3$ \\
\hline Bilcümle pembe-i ham Rumeli & Kantar (1) & 205 & 00 & 1860 & 620 \\
\hline Pişmiş kavsala-i manda ve karasığır & Adet (1) & 115 & 00 & 1043 & 348 \\
\hline Kavsala-i Aydın & Adet (1) & 30 & 00 & 272,5 & 90,5 \\
\hline Kavsala-i Gerede & Adet (1) & 30 & 00 & 272,5 & 90,5 \\
\hline Kavsala-i (?) & Adet (1) & 45 & 00 & 408 & 163 \\
\hline Sade Kavsala Bilecik & Çift (1) & 36 & 00 & 326,5 & 109 \\
\hline Beledî-i Bursa & Çift (1) & 17 & 00 & 154,5 & 51,5 \\
\hline Beledî-i Merzifon & Çift (1) & 23 & 00 & 208,5 & 39,5 \\
\hline Kutn-i Haleb & Tob (1) & 45 & 00 & 408 & 163 \\
\hline Kutn-i Bursa & Tob (1) & 67 & 20 & 612 & 204 \\
\hline Kutn-i Şam & $\operatorname{Tob}(1)$ & 65 & 20 & 590 & 196 \\
\hline Varil tahtası & Rayicinden & - & - & $\% 9$ & $\% 3$ \\
\hline Keçe-i Karahisar beyaz ve elvan & Adet (1) & 10 & 00 & 91 & 30 \\
\hline Keçe-i gaşiye & Adet (1) & 20 & 00 & 182 & 60 \\
\hline Mecidiye tabir olunur fes Tunus & Adet (4), Kâğıt (1) & 100 & 00 & 907 & 302 \\
\hline Alâ ve edna kebir fes Tunus & Adet (4), Kâğıtt (1) & 170 & 00 & 1542 & 514 \\
\hline Sağir fes Tunus alâ ve evsat ve edna & Adet (12), Deste (1) & 170 & 00 & 1542 & 514 \\
\hline Bilcümle kuru incir & Rayicinden & - & - & $\% 9$ & $\% 3$ \\
\hline Bilcümle rişte-i Ankara & Kiyye (1) & 30 & 00 & 272,5 & 90 \\
\hline Rişte-i Beypazarı & Kiyye (1) & 5 & 00 & 45 & 15 \\
\hline Rişte-i Karacalar & Kiyye (1) & 17 & 00 & 155 & 51 \\
\hline Rişte-i Kastamonu & Kiyye (1) & 10 & 00 & 91 & 30 \\
\hline Rişte-i Sürmen & Kiyye (1) & 13 & 20 & 122,5 & 41 \\
\hline Rişte-i keten Anadolu & Kiyye (1) & 7 & 20 & 68 & 22,5 \\
\hline Hamlama-i tire tabir olunur ketan ipliği & Kiyye (1) & 15 & 00 & 136 & 45 \\
\hline Rişte-i Markol (?) & Kiyye (1) & 8 & 00 & 73 & 24 \\
\hline Rişte-i Manastır & Rayicinden & - & - & $\% 9$ & $\% 3$ \\
\hline Rişte-i penbe izmir beyaz ve elvan & Kiyye (1) & 12 & 00 & 109 & 63 \\
\hline Rişte-i Tura/Töre & Kiyye (1) & 20 & 00 & 181 & 60 \\
\hline Her nevi peynir & Rayicinden & - & - & $\% 9$ & $\% 3$ \\
\hline Alâ ve edna cümle mazı & Kantar (1) & 300 & 00 & 2722 & 907 \\
\hline İşlenmiş alâ beyaz kitre & Kiyye (1) & 19 & 00 & 173 & 57,5 \\
\hline Evsat kitre & Kiyye (1) & 10 & 00 & 91 & 30 \\
\hline Edna kitre & Kiyye (1) & 3 & 20 & 32 & 10,5 \\
\hline Zamk Arabi & Kiyye (1) & 6 & 20 & 59 & 19,5 \\
\hline Sanduka & Kiyye (1) & 5 & 00 & 46 & 15 \\
\hline Bilcümle (...) & Kiyye (1) & 4 & 20 & 41 & 12,5 \\
\hline Hinta & Kiyye (20), Kile (1) & 14 & 00 & 127 & 42 \\
\hline Kokoroz ve çavdar & Kiyye (20), Kile (1) & 7 & 00 & 63,5 & 21 \\
\hline
\end{tabular}




\begin{tabular}{|c|c|c|c|c|c|}
\hline Akbaş peştamal & Çift (1) & 12 & 20 & 113,5 & 38 \\
\hline Fota-i Bursa & Çift (1) & 37 & 00 & 336 & 112 \\
\hline Peştamal Bursa & Çift (1) & 14 & 00 & 128 & 42 \\
\hline Telli fota-i Hama & Çift (1) & 90 & 00 & 816,5 & 272 \\
\hline Sade fota-i Hama & Çift (1) & 45 & 00 & 408 & 136 \\
\hline Peştamal Selanik & Çift (1) & 20 & 00 & 181 & 60 \\
\hline Helva ve bulama & Rayicinden & - & - & $\% 9$ & $\% 3$ \\
\hline Beyaz ve elvan ihram Rumeli & Kiyye (1) & 27 & 00 & 245 & 81,5 \\
\hline Günlük tuz & Kantar (1) & 82 & 20 & 748,5 & 249,5 \\
\hline Çivit Misır & Rayicinden & - & - & $\% 9$ & $\% 3$ \\
\hline Çit Kastamonu ve yorgan yüzü & Tob (12), Denk (1) & 800 & 00 & 7257 & 2419 \\
\hline Kıbrıs yastık ve bohça & Tob (1) & 16 & 00 & 145 & 48,5 \\
\hline Kıbrıs yorgan yüzü ve sofra & $\operatorname{Tob}(1)$ & 10 & 00 & 91 & 30 \\
\hline Kıbrıs döşek & $\operatorname{Tob}(1)$ & 16 & 00 & 145 & 48,5 \\
\hline Kibris takim & $\operatorname{Tob}(1)$ & 80 & 00 & 726 & 242 \\
\hline Çift yorgan yüzü tokat ve elvan & $\operatorname{Tob}(1)$ & 7 & 00 & 63,5 & 21 \\
\hline Yapağı Anadolu ve Rumeli ve Dersaadet & Kantar (1) & 145 & 00 & 1315 & 438,5 \\
\hline $\begin{array}{c}\text { Şam ve Trablusgarp ve Bağdat ve ol } \\
\text { havaliden gelen yapağ } 1\end{array}$ & Kantar (1) & 102 & 20 & 930 & 310 \\
\hline Ecnas-1 kereste & Rayicinden & - & - & $\% 9$ & $\% 3$ \\
\hline $\begin{array}{l}\text { Bamya ve fasulye ve bakliyat ve nohut ve } \\
\text { mercimek vesaire }\end{array}$ & Rayicinden & - & - & $\% 9$ & $\% 3$ \\
\hline Çeki & Adet (1) & 10 & 00 & 91 & 30 \\
\hline S1ğgrdili & Rayicinden & - & - & $\% 9$ & $\% 3$ \\
\hline Sahtiyan-1 kayseri ve Eğin & Adet (5) & 65 & 00 & 590 & 196 \\
\hline $\begin{array}{c}\text { Siyah sahtiyan-1 Isparta ve İzmir ve Konya } \\
\text { ve Uşak }\end{array}$ & Adet (1) & 12 & 00 & 108 & 36 \\
\hline $\begin{array}{c}\text { Siyah sahtiyan-1 İslimye ve çırpan ve } \\
\text { mahal-i saire siyah ve sarı }\end{array}$ & Adet (1) & 8 & 20 & 77 & 26 \\
\hline Kırmızı sahtiyan Uşak ve Tosya & Adet (6) & 75 & 00 & 680 & 227 \\
\hline Al sahtiyan Ereğli ve Balıkesir & Adet (1) & 18 & 00 & 163 & 54 \\
\hline Al sahtiyan Rumeli & Adet (1) & 12 & 20 & 113,5 & 38 \\
\hline Mustakî (?) & Kiyye (70) Varil (1) & 2000 & 00 & 18.144 & 6048 \\
\hline Dane mustakî & Kiyye (1) & 40 & 00 & 363 & 121 \\
\hline Mahlep & Kiyye (1) & 5 & 00 & 45,5 & 15 \\
\hline Sülük & Kiyye (1) & 23 & 31 & 216 & 72 \\
\hline Pekmez & Rayicinden & - & - & $\% 9$ & $\% 3$ \\
\hline Güherçile Misır & Rayicinden & - & - & $\% 9$ & $\% 3$ \\
\hline Findik & Kantar (1) & 55 & 00 & 499 & 166 \\
\hline Ceviz & Kiyye (100) Kile (1) & 57 & 20 & 522 & 174 \\
\hline Roğan zeyt & Kantar (1) & 180 & 00 & 1633 & 544 \\
\hline Afyon & Kiyye (1) & 140 & 00 & 1270 & 423 \\
\hline Afyon-1 Misır & Rayicinden & - & - & $\% 9$ & $\% 3$ \\
\hline
\end{tabular}




\begin{tabular}{|c|c|c|c|c|c|}
\hline Zernih & Kiyye (1) & 3 & 20 & & \\
\hline Şiar & Kiyye (14), Kile (1) & 6 & 10 & 56,5 & 19 \\
\hline Köfter (?) & Kantar (1) & 100 & 00 & 907 & 302 \\
\hline Cild-i kuzu ve sağir keçi & Adet (1) & 1 & 20 & 13,5 & 4,5 \\
\hline Kuzu ve tuzlu $(\ldots)$ ve kebir manda & Rayicinden & - & - & $\% 9$ & $\% 3$ \\
\hline Beyaz ve elvan post Ankara & Rayicinden & - & - & $\% 9$ & $\% 3$ \\
\hline Cild-i arneb Anadolu & Adet (100) & 100 & 00 & 907 & 302 \\
\hline Cild-i arneb Rumeli & Adet (100) & 60 & 00 & 544 & 181,5 \\
\hline Cild-i koyum ve keçi & $\operatorname{Adet}(1)$ & 2 & 30 & 25 & 8 \\
\hline Meşin Anadolu ve Rumeli & $\operatorname{Adet}(1)$ & 3 & 20 & 32 & 10,5 \\
\hline Almeşin Anadolu & Adet (1) & 7 & 20 & 68 & 22,5 \\
\hline Al meşin Rumeli & Adet (1) & 5 & 20 & 50 & 16,5 \\
\hline Bilcümle tiftik & Kiyye (1) & 14 & 10 & 129 & 43 \\
\hline Bilcümle tuzlu balık & Rayicinden & - & - & $\% 9$ & $\% 3$ \\
\hline Deve kuşu tüyü & Rayicinden & - & - & $\% 9$ & $\% 3$ \\
\hline İzmir'de husule gelen meyan balı & Kantar (1) & 110 & 00 & 998 & 233 \\
\hline Balık A $\breve{g}_{1}$ & Kiyye (1) & 20 & 00 & 181,5 & 60,5 \\
\hline Neşter Misır & Kiyye (1) & 11 & 00 & 100 & 33 \\
\hline Salep Anadolu & Kiyye (1) & 15 & 00 & 136 & 45,5 \\
\hline Salep Rumeli & Rayicinden & - & - & $\% 9$ & $\% 3$ \\
\hline Sabun & Kantar (1) & 176 & 00 & 1596 & 532 \\
\hline Donluk Şal Tunus & Adet (1) & 60 & 00 & 544 & 181 \\
\hline Beyaz Şal Tunus & Adet (1) & 18 & 00 & 163 & 54 \\
\hline Elvan Şal Tunus & Adet (1) & 50 & 00 & 454 & 151 \\
\hline Şal Tunus & Adet (1) & 50 & 00 & 454 & 151 \\
\hline Şal Karacalar & $\operatorname{Adet}(1)$ & 14 & 00 & 127 & 42 \\
\hline Enli ve ensiz sof ve şal-1 Ankara & Tob (1) & 35 & 00 & 3175 & 1058 \\
\hline Elvan şal-1 Tosya ve Talat & Rayicinden & - & - & $\% 9$ & $\% 3$ \\
\hline Kenevir & Kiyye (1), Kile (1) & 14 & 00 & 127 & 42 \\
\hline Ketan & Kiyye (1), Kile (1) & 21 & 00 & 190,5 & 63,5 \\
\hline Bilcümle harir-i ham & Kiyye (1) & 155 & 00 & 1406 & 468 \\
\hline $\begin{array}{l}\text { Harir-i ham Edirne ve Dimetoka ve Filibe } \\
\text { ve Pazarcık }\end{array}$ & Kiyye (1) & 122 & 00 & 1107 & 369 \\
\hline $\begin{array}{l}\text { Aydın ve Sığla ve Menteşe ve Şam ve } \\
\text { Haleb ve Sayda ve Beyrut harir-i ham }\end{array}$ & Kıyye (1) & 92 & 00 & 835 & 278 \\
\hline $\begin{array}{c}\text { Harir-i ham Yanya ve Tirhala ve Beyşehir } \\
\text { ve Selanik ve Amasya ve Çarşamba ve } \\
\text { Bafra }\end{array}$ & Kiyye (1) & 113 & 00 & 1025 & 342 \\
\hline Harir-i Kayseri & Kiyye (1) & 70 & 00 & 635 & 211,5 \\
\hline Bilcümle zımpara & Kantar (1) & 20 & 00 & 180 & 60 \\
\hline Sünger & Rayicinden & - & - & $\% 9$ & $\% 3$ \\
\hline Sade ve telli sofra maa peşkir Hama & $\operatorname{Adet}(1)$ & 180 & 00 & 1632 & 544 \\
\hline Mehir papas & $\operatorname{Tob}(1)$ & 30 & 00 & 272,5 & 90,5 \\
\hline
\end{tabular}




\begin{tabular}{|c|c|c|c|c|c|}
\hline Mehir Tosya & Tob (1) & 20 & 00 & 181,5 & 60 \\
\hline $\begin{array}{l}\text { Memalik-i Mahrûsa-i Şahane mahsulü } \\
\text { bilcümle duhan }\end{array}$ & Rayicinden & - & - & $\% 9$ & $\% 3$ \\
\hline Göbek bohça & Kiyye (1) & 10 & 13 & 94 & 31 \\
\hline Kenevir bohça & Kiyye (1) & 8 & 00 & 72,5 & 24 \\
\hline Bohça & Kiyye (1) & 6 & 20 & 59 & 19,5 \\
\hline Seccade-i kavala büyük ve küçük & Rayicinden & - & - & $\% 9$ & $\% 3$ \\
\hline Halı Uşak & Kiyye (1) & 16 & 00 & 145 & 84 \\
\hline Kilim Türkmen & Adet (1) & 75 & 00 & 680 & 227 \\
\hline Astar Kastamonu & Tob (60), Denk (1) & 550 & 00 & 4990 & 1663 \\
\hline Astar & Tob (1) & 10 & 00 & 91 & 31 \\
\hline Astar Hamid & Kiyye (1) & 22 & 00 & 200 & 66 \\
\hline Astar Taşköprü & Tob (1) & 6 & 00 & 54 & 18 \\
\hline Kirpas Alaiye Enli & Tob (1) & 9 & 00 & 81 & 27 \\
\hline Kirpas Alaiye Ensiz & Tob (1) & 7 & 00 & 63,5 & 21 \\
\hline Kirpas enli ensiz & Tob (50), Denk(1) & 410 & 00 & 3720 & 1240 \\
\hline Kirpas Dağ & Tob (1) & 14 & 00 & 127 & 42 \\
\hline Kirpas Dirama & Tob (1) & 19 & 00 & 172,5 & 57,5 \\
\hline Kirpas Ladik & Tob (1) & 5 & 00 & 45,5 & 15 \\
\hline Kirpas Ketan Anadolu & Kiyye (1) & 14 & 00 & 127 & 42 \\
\hline Kirpas Malatya & Tob (1) & 22 & 20 & 204 & 97 \\
\hline Kirpas menemen & Tob (1) & 11 & 00 & 100 & 33 \\
\hline Kirpas Merzifon & Zira' (1200), Denk (1) & 880 & 00 & 7984 & 2661 \\
\hline Kirpas Trabzon & Tob (1) & 25 & 00 & 227 & 76 \\
\hline Kirpas Rize & Kiyye (1) & 70 & 00 & 635 & 211 \\
\hline Kirpas Kastamonu & Zira' (1) & 1 & 00 & 9 & 3 \\
\hline Üzüm Karaburun ve çekirdeksiz & Kantar (1) & 130 & 00 & 1179 & 393 \\
\hline Çeşme mahsulü çekirdeksiz üzüm & Kantar (1) & 100 & 00 & 907 & 303 \\
\hline Bilcümle kuş üzümü & Kantar (1) & 112 & 20 & 1021 & 340 \\
\hline Sisam üzümü & Kantar (1) & 32 & 00 & 290 & 97 \\
\hline Urla çekirdeksiz üzüm & Kantar (1) & 118 & 20 & 1066 & 355 \\
\hline $\begin{array}{l}\text { Urla ve Çeşme ve Aydın ve Menteşe } \\
\text { Mahsulü Üzüm }\end{array}$ & Kantar (1) & 70 & 00 & 635 & 212 \\
\hline Üzüm siyah & Kantar (1) & 34 & 00 & 308 & 103 \\
\hline Üzüm Karaburun & Kantar (1) & 80 & 00 & 726 & 242 \\
\hline Bilcümle palamut & Kantar (1) & 52 & 20 & 476 & 159 \\
\hline Kibris hamr & Kiyye (1) & - & - & - & - \\
\hline Adi hamr her nevi & Kiyye (1) & 1 & 25 & 15 & 5 \\
\hline Safran Anadolu ve Rumeli & Rayicinden & - & - & $\% 9$ & $\% 3$ \\
\hline Asfur Anadolu & Kiyye (1) & 15 & 00 & 136,5 & 45 \\
\hline Asfur Misır & Rayicinden & - & - & $\% 9$ & $\% 3$ \\
\hline
\end{tabular}

Kaynak: BOA, A.DVN.NMH, 39/18, s.1-34; 67/11 Numaralı Nemçe Ahkam Defteri, M.1839-1868/ H.12551285.s.144-173 
Tablo 21851 Tarihli Tarife Defterinde Yer Alan Avusturya Devleti Ürünleri (Örnek)

\begin{tabular}{|c|c|c|c|c|}
\hline \multirow[b]{2}{*}{ Ürün Cinsi } & \multirow[b]{2}{*}{ Vezni ve Miktarı } & \multicolumn{2}{|c|}{ Kıymeti } & \multirow{2}{*}{$\begin{array}{c}\text { Vergi \% } 3 \\
\text { (Akçe) }\end{array}$} \\
\hline & & Kuruş & Para & \\
\hline Çelik & Kantar (1) & 160 & 00 & 461 \\
\hline Sirke & Kantar (1) & 35 & 00 & 101 \\
\hline Kolonya Suyu & Kutu 1/Şişe 6 & 15 & 00 & 42 \\
\hline Limon suyu & Kantar (1) & 66 & 00 & 190 \\
\hline Kezzap Suyu & Kiyye (1) & 4 & 20 & 13 \\
\hline Neft Yağ1 & Kiyye (1) & 13 & 25 & 13 \\
\hline İğne & 1 Deste, Adet (5000) & 205 & 00 & 59,5 \\
\hline Toplu İğne & 1 Deste, Adet (1000) & 5 & 00 & 14 \\
\hline İğne & 1 Deste, Adet (4000) & 35 & 00 & 101 \\
\hline Mineli İğne & Rayicinden & - & - & $\% 3$ \\
\hline Şalaki & Zira' & 11 & 20 & 11 \\
\hline Sarı Sabur & Kiyye (1) & 8 & 20 & 21,5 \\
\hline Şap & Kantar (1) & 50 & 00 & 144 \\
\hline Balık oltası ve iğnesi & Rayicinden & - & - & $\% 3$ \\
\hline Nişasta & Kiyye (1) & 3 & 20 & 10 \\
\hline Bahar-1 cedit & Kiyye (1) & 6 & 00 & 18 \\
\hline Timur lengir sefine & Kantar (1) & 11 & 00 & 317 \\
\hline Timur bozan & Kantar (1) & 25 & 00 & 720 \\
\hline Sim evâni & Dirhem (1) & 4 & 00 & 11,5 \\
\hline Civa & Kiyye (1) & 60 & 00 & 173 \\
\hline Fil Dişi & Kantar (1) & 70 & 00 & 202 \\
\hline Laciverd Boya & Kiyye (1) & 5 & 10 & 15 \\
\hline Roğan pelesenk & Kiyye (1) & 19 & 00 & 54 \\
\hline Ağaç marka tesmiye olunur edna fes & 1 Deste, Adet (12) & 20 & 20 & 59 \\
\hline Safir fes & 1 Deste, Adet (12) & 46 & 00 & 132 \\
\hline Mecidiye tabir olunur fes & 1 Deste, Adet (12) & 72 & 20 & 209 \\
\hline Esfidaç Ceneviz & Kantar (1), Sandık (2) & 205 & 00 & 590 \\
\hline Esfidaç Trieste & Rayicinden & - & - & $\% 3$ \\
\hline Mine Farisi (?) & Kiyye (1) & 28 & 00 & 80 \\
\hline Süt (fiçı içinde) & Kiyye (1) & 12 & 00 & 24 \\
\hline Çivid & Kiyye (1) & 12 & 00 & 24 \\
\hline Tenkâr (?) & Kiyye (1) & 10 & 00 & 29 \\
\hline Ağaç saplı çakı & Deste (1), Adet (12) & 2 & 20 & 7 \\
\hline Penbe ve tire çorap & Deste (1), Adet (12) & 18 & 20 & 53,5 \\
\hline Penbe ve tire kalice & Deste (1), Çift (12) & 32 & 20 & 94 \\
\hline Penbe ve tire çocuk çorabı & Deste (1), Çift (12) & 17 & 00 & 49 \\
\hline Ketan çorap & Deste (1), Çift (12) & 40 & 00 & 115 \\
\hline
\end{tabular}




\begin{tabular}{|c|c|c|c|c|}
\hline Yün çorap & Deste (1), Çift (12) & 35 & 00 & 101 \\
\hline Yün kalice & Deste (1), Çift (12) & 70 & 00 & 200 \\
\hline Çıngırak & Kutu (1) & 45 & 00 & 129 \\
\hline Balık yağından mum & Kiyye (1) & 27 & 20 & 79 \\
\hline İstiridye mumu & Kiyye (1) & 17 & 00 & 49 \\
\hline Reçine bayağı & Kiyye (1) & 13 & 00 & 37,5 \\
\hline Timur top & Rayicinden & - & - & $\% 3$ \\
\hline Zer ve sim sirma ve tirtıl ve til ve pul & Miskal (1) & 5 & 10 & 15 \\
\hline Pul ve tırtıl ve til & Kiyye (1) & 70 & 00 & 202 \\
\hline Şapka-1 Nemçe ve keçe şapka & Rayicinden & - & - & $\% 3$ \\
\hline Nemçe alâ hasır şapka & Deste (1), Adet (12) & 300 & 00 & 864 \\
\hline Nemçe evsat hasır şapka & Deste (1), Adet (12) & 220 & 00 & 634 \\
\hline Nemçe edna hasır şapka & Deste (1), Adet (12) & 75 & 00 & 216 \\
\hline Çocuk için Nemçe hasır şapka & Rayicinden & - & - & $\% 3$ \\
\hline Nemçe hasır şapka & Rayicinden & - & - & $\% 3$ \\
\hline Maden kömürü & Kantar (1) & 7 & 00 & 20 \\
\hline Lehm hınzır tuzlu ve bastırma & Kantar (1) & 117 & 20 & 338,5 \\
\hline Nemçe mahsulü kâğıt & Kiyye (1) & 8 & 20 & 24,5 \\
\hline Elvan kâğıt & Kiyye (1) & 8 & 20 & 24,5 \\
\hline $\begin{array}{l}\text { Her cins kebir ve sağir beyaz ve elvan posta kâğıt } \\
\text { Nemçe, her cins ve her renk posta kâğıdı Nemçe }\end{array}$ & Kıyye (1) & 11 & 00 & 31,5 \\
\hline Yaldızlı kâğıt & Rayicinden & - & - & $\% 3$ \\
\hline Kâğıt Nemçe kebir battal & Örse (1) & 160 & 00 & 461 \\
\hline Kâğgt & Örse (1) & 235 & 00 & 677 \\
\hline Nemçe mahsulü kâğıtt & Örse (1) & 25 & 00 & 72 \\
\hline Kâğıt sigara & Rayicinden & - & - & $\% 3$ \\
\hline Kâğğt (...) Nemçe & Örse (1) & 80 & 00 & 230 \\
\hline Kâğıt alâ battal & Örse (1) & 325 & 00 & 936 \\
\hline Kâğıt Nemçe & Örse (1) & 25 & 00 & 72 \\
\hline Kâğıt la'ib & Deste (1), Takım (12) & 11 & 00 & 32 \\
\hline Katran Avusturya & Kantar (1) & 40 & 00 & 115 \\
\hline Mühür mumu Avusturya & Rayicinden & - & - & $\% 3$ \\
\hline Şema' asel mamul & Kantar (1) & 900 & 00 & 2592 \\
\hline Bilcümle sepet & Rayicinden & - & - & $\% 3$ \\
\hline Nemçekârî adi toprak fincan & Adet (100) & 60 & 00 & 172 \\
\hline Kina & Rayicinden & - & - & $\% 3$ \\
\hline Hırdavat ve ayna ve çini & Rayicinden & - & - & $\% 3$ \\
\hline Mismar Trieste & Kantar (1) & 140 & 00 & 403 \\
\hline Kabare & Adet (500), Kâğıt (5) & 11 & 00 & 32 \\
\hline Zencefil & Kiyye (1) & 62 & 00 & 178 \\
\hline Çikolata & Kiyye (1) & 15 & 00 & 43 \\
\hline Kırmız & Kıyye (1) & 77 & 20 & 223 \\
\hline
\end{tabular}




\begin{tabular}{|c|c|c|c|c|}
\hline Reçine & Kantar (1) & 26 & 00 & 75 \\
\hline Kemik ve boynuz saplı bayağı çatal ve bıçak & Deste (1), Adet (24) & 12 & 20 & 36 \\
\hline Boncuk & Tob (25), Kâğgtt (1) & 20 & 00 & 58 \\
\hline Kaya boncuk & Kiyye (1) & 6 & 00 & 17 \\
\hline Tespihlik alâ mercan & Kiyye (1) & 1250 & 00 & 3600 \\
\hline Evsat mercan & Kiyye (1) & 600 & 00 & 1728 \\
\hline Edna mercan & Kiyye (1) & 190 & 00 & 547,5 \\
\hline Ham mercan & Kiyye (1) & 600 & 00 & 1728 \\
\hline Harir ve gaz ve atlas ve sair nevi kurdele ve bağ & Rayicinden & - & - & $\% 3$ \\
\hline Yün şerit & Rayicinden & - & - & $\% 3$ \\
\hline Karim tatar & Kiyye (1) & 8 & 10 & 23,5 \\
\hline Enli ve ensiz bürümcek harir Nemçe & Tob (1) & 100 & 00 & 288 \\
\hline Boya & Kiyye (1) & 7 & 00 & 20 \\
\hline Kalaylı timur kaşık kebir Nemçe & Deste (1), Adet (12) & 25 & 00 & 72 \\
\hline Kalaylı timur kaşık safir Nemçe & Deste (1), Adet (12) & 12 & 20 & 26 \\
\hline Zerdeçav & Kantar (1) & 140 & 00 & 403 \\
\hline Venedik ve Triestekâri hasırlı büyük şişe & Adet (1) & 16 & 00 & 46 \\
\hline $\begin{array}{l}\text { Çiçekli ve taraklı ve dallı ve çubuklu ve sair has ve } \\
\text { kalıb alâ ve evsat ve edna koton }\end{array}$ & Parça (1) & 1 & 10 & 3,5 \\
\hline $\begin{array}{l}\text { Bil cümle koton Nemçe eni altı buçuk ebattan altı } \\
\text { rab'a kadar }\end{array}$ & Parça (1) & 2 & 5 & 6Sar1 \\
\hline Sarı teneke ve timur ve kurşundan yüksek Nemçe & Adet (144) & 12 & 00 & 24,5 \\
\hline Trrpan kebir ve sağir & Adet (1) & 4 & 20 & 13 \\
\hline Maden marka tabir olunur beyaz ham tel & Kiyye (1) & 32 & 00 & 92 \\
\hline Nemçekârî rişte-i kire & Kiyye (1) & 18 & 00 & 52 \\
\hline İnce ve kalın timur tel Nemçe & Rayicinden & - & - & $\% 3$ \\
\hline Nemçekâri keman kirişi & Rayicinden & - & - & $\% 3$ \\
\hline Alâ ve edna ve evsat fanila-i Nemçe & Zira' (55), Tob (1) & 200 & 00 & 576 \\
\hline Kalaylı timur çatal Nemçe & Deste (1), Adet (12) & 25 & 00 & 72 \\
\hline Çubuklu ve kadifeli kalıptan saçak ve şerit & Miskal (1) & 5 & 00 & 14,5 \\
\hline Karanfil & Kiyye (1) & 12 & 00 & 24,5 \\
\hline Cila Nemçe & Kiyye (1) & 30 & 00 & 87 \\
\hline Bilcümle oyuncak & Rayicinden & - & - & $\% 3$ \\
\hline Beyaz ve elvan tireden mamul bayağı eldiven & Deste (1), Çift (12) & 19 & 00 & 55 \\
\hline Civid hind sandık ile gelen bengal tabir olunur. & Kiyye (1) & 67 & 20 & 194,5 \\
\hline Civid hind sandık ile gelen madras (?) tabir olunur & Kiyye (1) & 40 & 00 & 115 \\
\hline Makara telli Nemçe & $\begin{array}{c}\text { Dirhem (63), Deste } \\
\text { (1) }\end{array}$ & 7 & 00 & 20 \\
\hline Roğan hınzır & Kiyye (1) & 12 & 20 & 36 \\
\hline Sarı teneke ve til Nemçe & Kiyye (1) & 17 & 00 & 49 \\
\hline Samanlı iğne Nemçe adi & Deste (1) & 5 & 20 & 16 \\
\hline Kuyumcu iğnesi & Deste (1), Adet (12) & 13 & 00 & 37 \\
\hline Badem içi & Kiyye (1) & 7 & 20 & 22,5 \\
\hline Havlu & Rayicinden & - & - & $\% 3$ \\
\hline Çiçekli sahtiyan Nemçe & Deste (1), Adet (12) & 137 & 20 & 396 \\
\hline
\end{tabular}




\begin{tabular}{|c|c|c|c|c|}
\hline Elvan sahtiyan Nemçe & Deste (1), Adet (12) & 122 & 20 & 353 \\
\hline Enli ve ensiz merinos & Rayicinden & - & - & $\% 3$ \\
\hline Kuru balık & Kantar (1) & 75 & 00 & 216 \\
\hline Kal olunmamış Güherçile & Rayicinden & - & - & $\% 3$ \\
\hline Kal olunmuş Güherçile & Kantar (1) & 176 & 00 & 507 \\
\hline Ceviz Hindistan & Kıyye (1) & 50 & 00 & 144 \\
\hline Timur ve maden kulaklı gözlük & Deste (1), Adet (12) & 20 & 00 & 57,5 \\
\hline Kulaksız gözlük & Adet (60), Kutu (10) & 33 & 00 & 95 \\
\hline Reçine yağ 1 & Kiyye (1) & 11 & 00 & 32 \\
\hline Roğan saç & Kiyye (1) & 2 & 30 & 8 \\
\hline Her nevi büyük ve küçük şemsiye & Rayicinden & - & - & $\% 3$ \\
\hline Kurşun saçma & Kantar (1) & 130 & 00 & 375 \\
\hline $\begin{array}{l}\text { Çuka, feracelik, pantolonluk düz, çubuklu bilcümle } \\
\text { ala, evsat, edna, taklidi ve İngiliz taklidi tabir olunur. }\end{array}$ & Rayicinden & - & - & $\% 3$ \\
\hline Çuka-i Nemçe & Zira' (1) & 31 & 00 & 89 \\
\hline Taklidi ve mahur çuka-i Nemçe & Zira' (1) & 23 & 20 & 68 \\
\hline Çuka-i Nemçe çifte balık (...) tabir olunur. & Zira' (1) & 11 & 00 & 31 \\
\hline Çuka-i Nemçe mahur saray & Zira' (1) & 17 & 00 & 49 \\
\hline Çuka-i Nemçe enli & Zira' (1) & 15 & 20 & 44,5 \\
\hline Çuka-i Nemçe ensiz & Zira' (1) & 8 & 20 & 14,5 \\
\hline Trieste patatesi & Kantar (1) & 30 & 00 & 86,5 \\
\hline Zift Avusturya & Kantar (1) & 20 & 00 & 58 \\
\hline $\begin{array}{c}\text { Tane ve beyaz ve siyah ve battal parlak sahtiyan } \\
\text { Avusturya }\end{array}$ & Deste (1), Adet (12) & 375 & 00 & 1080 \\
\hline Avusturya mahsulü roganlı sahtiyan elvan & Deste (1), Adet (12) & 400 & 00 & 1152 \\
\hline Biber & Kiyye (1) & 4 & 00 & 11,5 \\
\hline Sahte inci & Dizi (10), Tob (1) & 14 & 00 & 40 \\
\hline Bayağ & Rayicinden & - & - & $\% 3$ \\
\hline Tarak & Deste (5), Adet (60) & 25 & 00 & 72 \\
\hline Kurşun külçe & Kantar (1) & 115 & 00 & 331 \\
\hline Bilcümle toprak tabak ve çay ve sofra takımı & Rayicinden & - & - & $\% 3$ \\
\hline Zerver & Kiyye (1) & 90 & 00 & 259 \\
\hline Sucuk ve bastırma & Kiyye (1) & 16 & 00 & 46 \\
\hline İngiliz (...) tesmiye olunur ecza & Kıyye (1) & 45 & 00 & 130 \\
\hline Trieste sabunu & Rayicinden & - & - & $\% 3$ \\
\hline Beyaz ve sarı tenekeden zarf neme & Deste (1), Adet (12) & 12 & 00 & 24,5 \\
\hline Zenne ve çocuk kundurası Nemçe & Rayicinden & - & - & $\% 3$ \\
\hline Erkek kundurası Nemçe & Çift (1) & 24 & 00 & 69 \\
\hline Kahli Ağaç küte Nemçe & $(1)$ & 800 & 00 & 2304 \\
\hline Aynalı teneke kutu Nemçe & Deste (1), Adet (12) & 4 & 20 & 13 \\
\hline Her cins kılıç ve tüfek ve piştov ve sair & Rayicinden & - & - & $\% 3$ \\
\hline
\end{tabular}




\begin{tabular}{|c|c|c|c|c|}
\hline $\begin{array}{l}\text { Bilcümle basma şalı ve penbe ve harir ve ketan-i } \\
\text { Nemçe }\end{array}$ & Rayicinden & - & - & $\% 3$ \\
\hline Adi esvab firçası Nemçe & Deste (1), Adet (12) & 45 & 00 & 130 \\
\hline Kundura firçası Nemçe & $\begin{array}{l}\text { Kutu (1), Kâğgtt (10), } \\
\text { Adet (10) }\end{array}$ & 42 & 20 & 122 \\
\hline Limon ve portakal kabuğu & Kiyye (1) & 3 & 00 & 8,5 \\
\hline Horasani & Kiyye (1) & 17 & 00 & 49 \\
\hline $\begin{array}{l}\text { Nemçe mahsulü olarak düz canfes ve atlas ve } \\
\text { lavantin }\end{array}$ & $\operatorname{Arşın~(1)~}$ & 8 & 00 & 23 \\
\hline Nemçe-i mahsulü düz canfes ve atlas ve lavantin & $\operatorname{Arşın~(1)~}$ & 27 & 20 & 79 \\
\hline $\begin{array}{l}\text { Nemçe-i mahsulü (...) tabir olunur çiçekli canfes eni } \\
\text { altı raba'dan bir endazeye kadar. }\end{array}$ & Arşın (1) & 10 & 00 & 29 \\
\hline $\begin{array}{l}\text { Nemçe-i mahsulü }(\ldots) \text { tabir olunur harirden }(\ldots) \\
\text { tokası eni yarım endaze Nemçe mahsulü telli atlas }\end{array}$ & Rayicinden & - & - & $\% 3$ \\
\hline Sigara Almanya & Adet (1000) & 250 & 00 & 720 \\
\hline Mum & Deste (5), Adet (60) & 40 & 00 & 115 \\
\hline $\begin{array}{l}\text { Çıplak ayna beher sandığı on beş adetten otuz adede } \\
\text { kadar }\end{array}$ & Adet (60), Sandık (2) & 160 & 00 & 460 \\
\hline Ayna & Deste (1), Adet (12) & 6 & 20 & 18 \\
\hline Aynalı ve sair çekmece Nemçe & Rayicinden & - & - & $\% 3$ \\
\hline Kebir ve sağir çerçeveli ayna & Rayicinden & - & - & $\% 3$ \\
\hline Kalay & Kantar (1) & 550 & 00 & 1584 \\
\hline Çizme-i Nemçe & Çift (1) & 50 & 00 & 144 \\
\hline Kara günlük yağı & Kiyye (1) & 5 & 20 & 16 \\
\hline Avrupa mahsulü timur hindi & Kiyye (1) & 4 & 00 & 11 \\
\hline Tahta-i Trieste ve Venedik & $\operatorname{Adet}(100)$ & 500 & 00 & 1440 \\
\hline Ala ve edna ve evsat kirpas ketan ve sofra bezi & Rayicinden & - & - & $\% 3$ \\
\hline İş boyası & Kantar (1) & 32 & 00 & 95 \\
\hline $\begin{array}{c}\text { Tül ve gaz ve bürümcek işleme boyun bağ } 1 \text { ve } \\
\text { mendil }\end{array}$ & Rayicinden & - & - & $\% 3$ \\
\hline Penbeden basma kadife & Parça (1) & 4 & 20 & 13 \\
\hline Penbeden sade kadife & Parça (1) & 3 & 20 & 10 \\
\hline Harir ve penbe ile mahlût kadife & Zira' (1) & 22 & 20 & 65 \\
\hline Sade harir kadife & Rayicinden & - & - & $\% 3$ \\
\hline Cenkâr külçe & Kıyye (1) & 12 & 20 & 36 \\
\hline Kalem cenkâri & Kiyye (1) & 23 & 00 & 66 \\
\hline Venedik bayağ 1 şişe & Kaşun (1) & 935 & 00 & 2693 \\
\hline Saat camı & Rayicinden & - & - & $\% 3$ \\
\hline Pencere camı & Sanduk (2) & 137 & 20 & 396 \\
\hline Göztaş1 & Kiyye (1) & 5 & 00 & 14,5 \\
\hline Sarı tenekeden mengir & Kiyye (1) & 18 & 00 & 51 \\
\hline Zencefil beyaz ve sarı & Kantar (1) & 150 & 00 & 432 \\
\hline Kükürt & Kantar (1) & 58 & 00 & 466,5 \\
\hline Kükürt külçe & Kantar (1) & 42 & 00 & 121 \\
\hline
\end{tabular}

Kaynak: BOA, A.DVN.NMH, 39/18, s.1-34. 